\title{
La neCrópolis ibérica de El Carnoso, Andilla (La Serranía, Valencia)
}

The Iberian Necropolis of "El Carnoso", Andilla (La Serranía, Valencia)

\section{ANA SABATER PÉREZ ${ }^{1}$, JUAN JOSÉ RUIZ LÓPEZ ${ }^{2}$, JOSEP MARIA BURRIEL ALBERICH ${ }^{3}$, MATÍAS CALVO GÁLVEZ}

(1) Ayuntamiento de Andilla. ana.sabater.perez@gmail.com

(2) Museo Arqueológico de Chelva. juanjoruiz4@hotmail.com

(3) Museu Arqueològic Municipal de Moncada.museu@moncada.es

(4) Museo Arqueológico de Sagunto.calvo_mat@gva.es

\section{RESUMEN:}

El presente artículo da cuenta de las excavaciones efectuadas en el sector norte de la necrópolis ibérica del conjunto arqueológico de El Carnoso de Andilla (Valencia). Necrópolis que estuvo en funcionamiento como mínimo durante el s. V a.C. y que hasta la fecha presenta dos modalidades de sepulturas: cubrición tumular y cremación en hoyo. Desafortunadamente las dos estructuras tumulares documentadas fueron expoliadas en el s.XVI, lo que supuso la pérdida de la valiosísima información arqueológica que hubieran proporcionado los ajuares asociados. Tras la excavación efectuada, la necrópolis ha sido vallada y las estructuras consolidadas.

Palabras clave: Iberos, sepulturas, cremación, ritual funerario, Serranía.

\section{Abstract:}

This article discusses about excavations that have taken place in the Northern Area of an Iberian Necropolis. This Archaeological site is known as "El Carnoso de Andilla (Valencia)". It was in operation at least during the 5th century B.C. So far, it shows two burial modes: tumular coverage and cremation hole. Unfortunately, the two documented structures were probably despoiled in the 16th century, this means the valuable loss of archaeological information that funerary offerings may have provided. Following the excavation, the area was fenced and structures were consolidated.

Key words:Iberians, burial, cremation, funerary ritual, Serranía. 


\section{INTRODUCCIÓN}

Los trabajos arqueológicos que se describen en el siguiente artículo se han centrado en la antigua necrópolis de El Carnoso II, y más concretamente sobre un área de $200 \mathrm{~m}^{2}$ en su límite N. En dicha área de intervención se han localizado tres sepulturas, dos estructuras tumulares y un loculus o cremación en hoyo. Las dos estructuras aparecieron expoliadas, muy probablemente en la primera mitad del s. XVI, ambas son de planta cuadrangular y no ofrecen dudas de su función como lugar de enterramiento. Además de estas sepulturas se han localizado fuera del perímetro intervenido en la I campaña (julioagosto de 2014), otras tantas estructuras constructivas que incluyen un posible peribolos, estando prevista su documentación arqueológica y consolidación arquitectónica en futuras intervenciones ${ }^{1}$.

Asimismo, el presente artículo se inscribe dentro de un proyecto de investigación más amplio impulsado por el Museo Arqueológico de Chelva y financiado por la Dirección General de Patrimonio Cultural de la Conselleria d'Educació, Investigació, Cultura i Esport de la Generalitat Valenciana y el Ayuntamiento de Andilla con el que se pretende analizar y caracterizar el paisaje cultural ibérico de la comarca valenciana de la Serranía, su hábitat y especialmente los aspectos asociados a la religiosidad y los lugares de culto.

\section{CONTEXTO GEOGRÁFICO. LA SERRANÍA VA- LENCIANA Y EL TÉRMINO DE ANDILLA}

La Serranía es una amplia comarca de la cuenca media del río Turia, ubicada al NO de la Comunidad Valenciana, limitando con las comunidades autónomas de Aragón y Castilla-La Mancha. Su extensión es de aproximadamente $1400 \mathrm{~km}^{2}$ y su medio físico, aunque muy diverso, se caracteriza sobre todo por ser muy montañoso. Este relieve accidentado delimita la comarca al N con la Sierra de Javalambre, al S con las sierras del Negrete, Juan Navarro, del Tejo y de Chiva, al E con los llanos del Camp de Túria y la sierra Calderona y al $\mathrm{O}$ con la sierra de Mira. Por lo que respecta a la red fluvial, cabe mencionar que el río Turia cruza de NO a SE toda la comarca, siendo el río más importante, el cual recibe el aporte de aguas de cuatro afluentes: los ríos Arcos, Regajo, Sot y Chelva. Además hay que añadir los cursos de circulación esporádica, como son el barranco de
Raga, la rambla de Arquela, el Reguero de La Yesa, la rambla de Alcotas, el río de Andilla-rambla de Artaj y la rambla de la Aceña.

En cuanto a la red viaria destacan sobre manera dos vías históricas, actualmente abandonadas: el Camino Real de Aragón y el Camino Real de Castilla, las cuales no sufren grandes cambios desde época medieval hasta que la administración borbónica del s. XVIII decide dar prioridad a otras vías. El antiguo Camino Real de Aragón a Valencia desde la Puebla de San Miguel (en Ademuz) entraba en la Serranía, después de cruzar el río Arcos, por Losilla de Aras, a continuación transitaba por La Yesa, seguía por la aldea de la Cervera (Abejuela) y Andilla, donde habría una parada obligada. Desde este último pueblo penetraba en el término de Llíria por el collado de La Losa, tras pasar por Casinos llegaba a Llíria por el Camí de la Iessa y de aquí a Valencia por Burjassot. Por otro lado estaba el Camino Real de Castilla, que desde Cuenca entraba en Valencia por la Serranía, primero cruzaba el término de Sinarcas, después, consecutivamente, Benagéber, Tuéjar, Chelva, Calles, Domeño, Losa del Obispo y Llíria para a continuación seguir hacia Valencia. Hasta finales del s. XVIII era la vía más rápida e importante para llegar desde Madrid y Cuenca a Valencia. Este camino pierde importancia con la construcción de caminos carreteros como el de la carretera de Almansa o Camino Real de Madrid (1765-1788) y el Camino de Madrid por Requena, actual N-III (1825-1851), repercutiendo económica, social y demográficamente en la Serranía. Desde 1884 a 1916 se construye la actual carretera Ademuz-Llíria dejando en desuso el antiguo Camino Real de Castilla. Estos dos ejes principales tenían a su alrededor todo un entramado de caminos de herradura secundarios que vertebraban totalmente el territorio y significativamente están jalonados de numerosos yacimientos ibéricos, romanos, tardoantiguos y andalusíes.

Andilla es un municipio situado al NE de la comarca de la Serranía, cuenta con una superficie de $142,8 \mathrm{~km}^{2}$, en la actualidad limita al $\mathrm{N}$ con los términos municipales de Abejuela (Teruel) y Sacañet (Castelló), al S con los términos de Higueruelas, Villar del Arzobispo y Llíria, al E con Alcublas y al O con La Yesa y Chelva. El modelo de poblamiento del municipio siempre fue polinuclear, integrado por cuatro asentamientos habitados, con capital municipal en Andilla y tres aldeas, La Pobleta, Osset y Artaj, incluso agrupaciones menores (las bodegas y pajares de Pardanchinos o Casa de los Sepes), estos núcleos poblacionales se asientan en lugares favorables para la agricultura y especialmente la ganadería de ovicaprinos. 
En cuanto al marco físico, el término municipal de Andilla se sitúa sobre las montañas del sistema Ibérico que se extienden desde la Sierra de Javalambre hasta la sierra Calderona. Es posible distinguir diversas unidades morfológicas de las que cabe destacar el arco montañoso dispuesto en torno a la Hoya de Andilla, en la porción septentrional del término; y el macizo de Los Altos y Puntal de Simón al O del término, que se extiende, desde los confines de los municipios de Abejuela e Higueruelas hasta la transición hacia el llano. Es precisamente en esta unidad física donde se localiza el conjunto arqueológico de El Carnoso. La red hidrográfica andillana pertenece, casi en su totalidad, a la cuenca del Turia, menos una pequeña porción del NE del término municipal que vierte al río Palancia (Rodrigo 1999) ${ }^{2}$.

\section{EL CONJUNTO ARQUEOLÓGICO}

El Conjunto Arqueológico de El Carnoso de Andilla (La Serranía, Valencia) está configurado hasta la fecha por tres elementos de primer orden y otros tantos valores patrimoniales de carácter etnográfico de especial interés para la investigación en curso. De estos otros valores destacamos el antiguo camino de herradura que va de Andilla a Villar del Arzobispo, vía de comunicación milenaria conocida como el camino de Los Tollos y en el que todavía se conservan algunos tramos empedrados.

\section{EL CARNOSO I}

Este yacimiento se sitúa en el extremo $\mathrm{N}$ del conjunto, fue una pequeña aldea ibérica amurallada instalada en la cima y ladera $S$ de un cerro-collado, a 949 m.s.n.m. El asentamiento estaba defendido por una muralla perimetral de ancho variable, entre $1 \mathrm{~m}$ y $1,5 \mathrm{~m}$, que se adapta a las curvas de nivel, de hecho, en algún tramo tiene un desarrollo curvilíneo. La aldea ocuparía aproximadamente $4900 \mathrm{~m}^{2}$ dispuestos en un mínimo de dos desniveles en los que se aprecian abundantes estructuras a ras del suelo y una posible torre en la parte más alta que debía flanquear a la puerta de acceso. En superficie se observa escasa cerámica cuya cronología es del Ibérico Pleno y Final. El entorno inmediato (barranco del Carnoso) es muy abrupto pero se ven abundantes aterrazamientos de origen incierto y que hasta hace 50 años estaban cultivados.

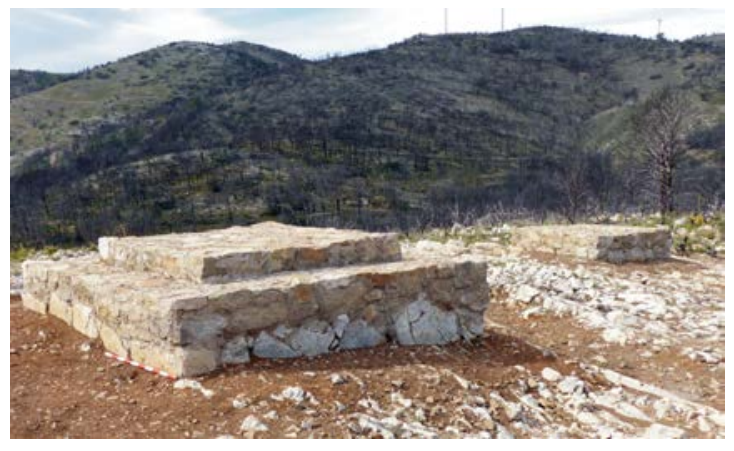

Fig. 1: Sector N de la necrópolis de El Carnoso II tras la consolidación arquitectónica. En primer plano la Sepultura 1.

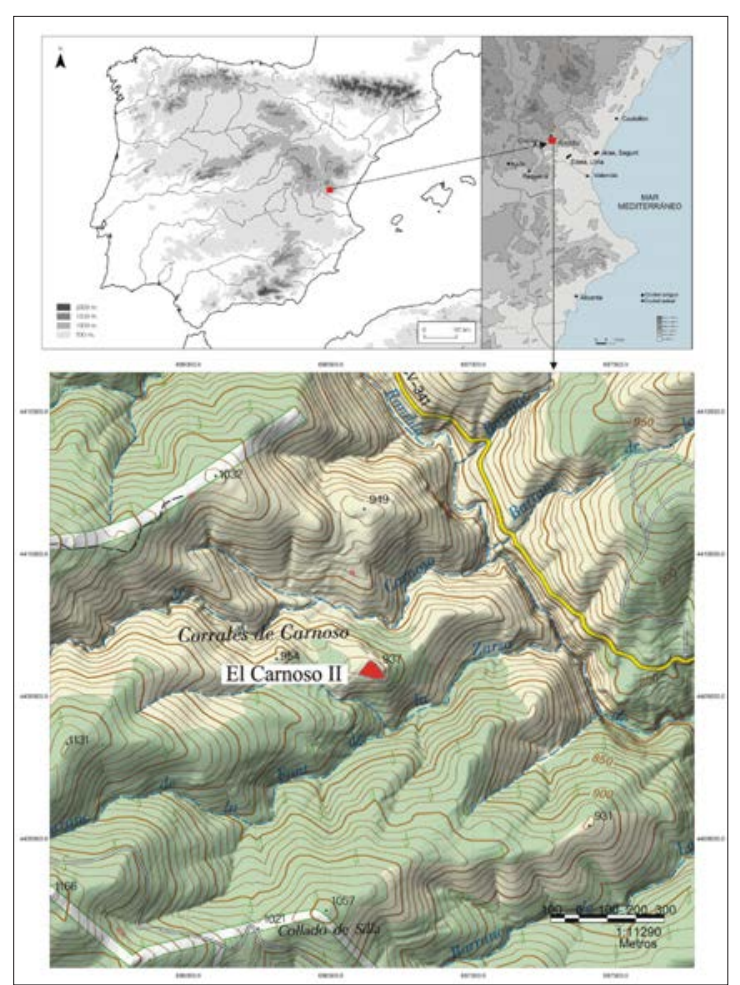

Fig. 2: Localización geográfica de la necrópolis ibérica de El Carnoso II.

\section{EL CARNOSO II}

Se localiza al S-SE de El Carnoso I, limitando al N con el barranco del Carnoso, al S con el barranco de la Fuente de la Zarza, al E con la rambla de Artaj y al O con las últimas estribaciones del Puntal de Simón. Pudo tratarse de la primera necrópolis del poblado (Ibérico 
Antiguo, ss. VI-V a.C.). Hasta el momento de su hallazgo, año 2012, era totalmente inédita.

\section{EL CARNOSO III}

Es un edificio aislado de planta rectangular de aproximadamente $15 \mathrm{~m} \times 7 \mathrm{~m}\left(105 \mathrm{~m}^{2}\right)$ compartimentado interiormente, orientado $110^{\circ}$ al $\mathrm{E}$ y de apariencia turriforme. A esta edificación protegida por escarpes naturales (lado $\mathrm{O}$ ) y un posible foso (flanco $\mathrm{S}$ ), se accede por el lado SE a través de una especie de rampa empedrada. Provisionalmente lo hemos clasificado como "edificio singular" al desconocer su auténtica funcionalidad. Su situación orográfica, a 950 m.s.n.m., a 500 m al SO del poblado de El Carnoso I y a $350 \mathrm{~m}$ al O de la necrópolis, le proporciona un gran dominio visual especialmente hacia el E.

Apenas se ve material cerámico en superficie. El poco existente, junto a la técnica constructiva y paralelos formales, permite su datación provisional dentro del Ibérico Pleno.

\section{LA NECRÓPOLIS DE EL CARNOSO}

De forma resumida diremos que El Carnoso II es una necrópolis tumular ibérica de cremación de cronología antigua, centrada en el s. V a.C., de las pocas conocidas en la comarca de la Serranía y Comunidad Valenciana. Tras la primera intervención arqueológica observamos que, aun habiendo sido expoliada, ha conservado suficiente entidad y abundantes restos materiales para iniciar el proceso de caracterización y puesta en valor. En ella se han documentado dos tipos de sepulturas, muy probablemente sincrónicas: estructuras tumulares de planta cuadrangular y alzados que no superarían el metro de altura y que en algún caso pudieron estar escalonadas; y sepulturas de cremaciones en hoyo sencillas. En ambos casos son deposiciones secundarias y por ahora no se han detectado busta o ustrina. Este tipo de necrópolis, como veremos más adelante, tiene numerosos paralelos en el área SE de la península Ibérica. Las citadas estructuras tumulares se levantaron con muros pétreos de sillarejos de tamaño medio y grande de muy buena factura que delimitan un espacio interior o nicho donde se depositaría la urna conteniendo los restos de la cremación del cadáver y los ajuares asociados, espacio que a continuación se sellaba con tierra y piedras. Esta necrópolis, como en otros lugares ibéricos, parece haber estado delimitada por un peribolos del que quedan muchas evidencias en el sector meridional y todo parece indicar que podría superar los $2000 \mathrm{~m}^{2}$ de superficie.

\section{EL HALLAZGO DE LA NECRÓPOLIS}

La necrópolis ibérica de El Carnoso II fue localizada el día 27 de noviembre de 2012, tres meses después del fatídico incendio forestal que arrasó la comarca de la Serranía valenciana, especialmente el término municipal de Andilla. El hallazgo se enmarcó en el trabajo de prospección

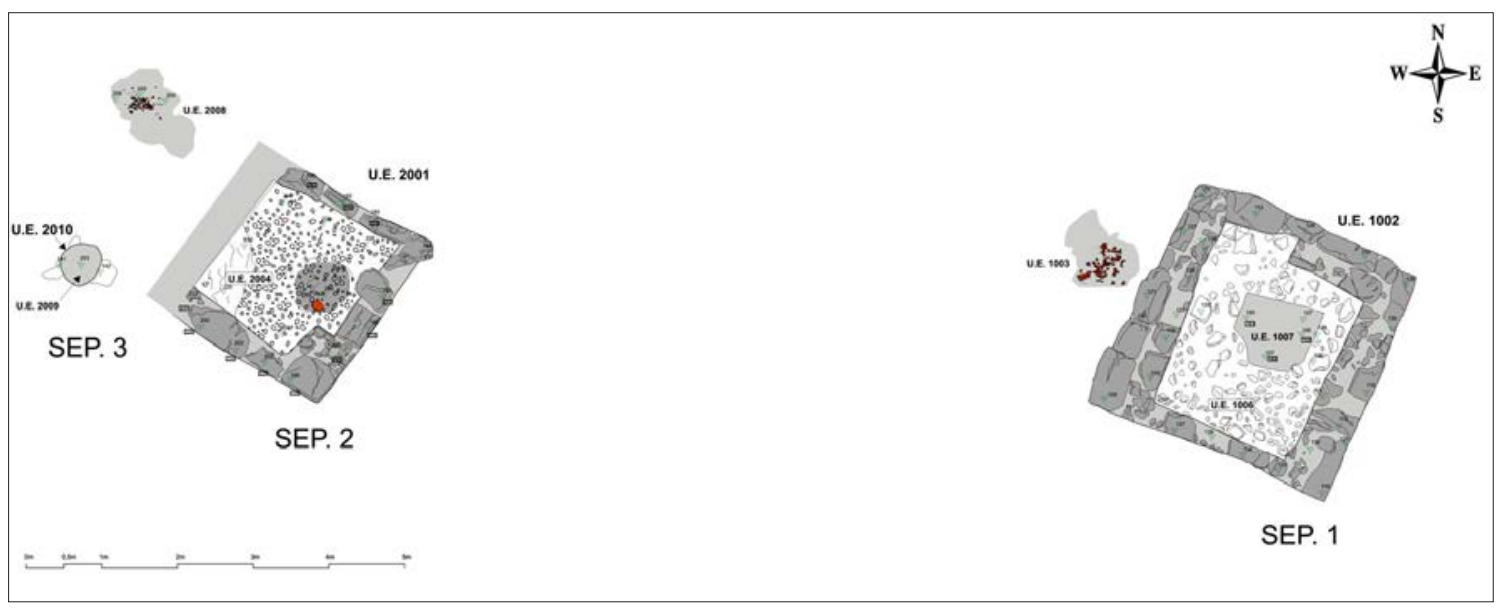

Fig. 3: Planta parcial de la necrópolis, año 2014. 
selectiva de los más de 120 yacimientos ibéricos inventariados en la comarca que de forma sistemática veníamos realizando desde hacía meses. Estas prospecciones tuvieron como objetivo principal analizar físicamente los yacimientos y sus entornos inmediatos, así como contrastar los datos con los que se contaba hasta ese momento a través del Inventario de Yacimientos de la Dirección General de Cultura y de otras publicaciones. Los resultados de los mencionados trabajos de prospección se han materializado en un artículo publicado en el número 47 de la revista Sagvntvm de la Universitat de València (Burriel y Ruiz 2015).

\section{ANTECEDENTES BIBLIOGRÁFICOS}

La primera referencia a uno de los tres yacimientos que configuran en la actualidad el conjunto arqueológico de El Carnoso, fue publicada por D. Vicente Llatas en 1969: Segunda relación de yacimientos arqueológicos del Villar del Arzobispo y su comarca (Llatas 1969: 8). En ella se hace una magnífica descripción del situado a $350 \mathrm{~m}$ al $\mathrm{O}$ de nuestra necrópolis que denomina Corrales de Carnoso y que actualmente identificamos como El Carnoso III pero no hay referencias a la necrópolis ni al poblado asociados.

Años más tarde, en 1984, el profesor J. Uroz cita el yacimiento de los Corrales de Carnoso en su trabajo sobre la Regio Edetania (Uroz 1984: 54) y en 1995, Miguel F. Aragón a partir de los hallazgos de materiales ibéricos en las proximidades del barranco Carnoso de Andilla elabora dos fichas de yacimiento arqueológico para el inventario de la Dirección General de la Conselleria d'Educació, Investigació, Cultura i Esport de la Generalitat Valenciana. Una de estas fichas, Corrales de Carnoso I, describe y sitúa el yacimiento de referencia en la margen derecha del barranco Carnoso de la siguiente manera:

Tipo: poblado. Adscripción: Ibérica. Cronología: IVIII aC. Periodo: (¿?), Conservación: Regular. Peligro: Alto, repoblación forestal y erosión. Estructuras: Sí, según la bibliografía. La espesura del monte bajo no permite constatar su existencia. Descripción: Cerámica ibérica de pastas finas y groseras y escoria de horno de hierro. Los restos citados están en un altozano de ladera abancalada, rodeado de escarpados barrancos. Plano catastral: Polígono 14, Parcelas 1a y 1c.

La fuente de información utilizada por Miguel F. Aragón para la elaboración de la ficha pudo ser la publicación de D. Vicente Llatas en 1969, aunque no se cita

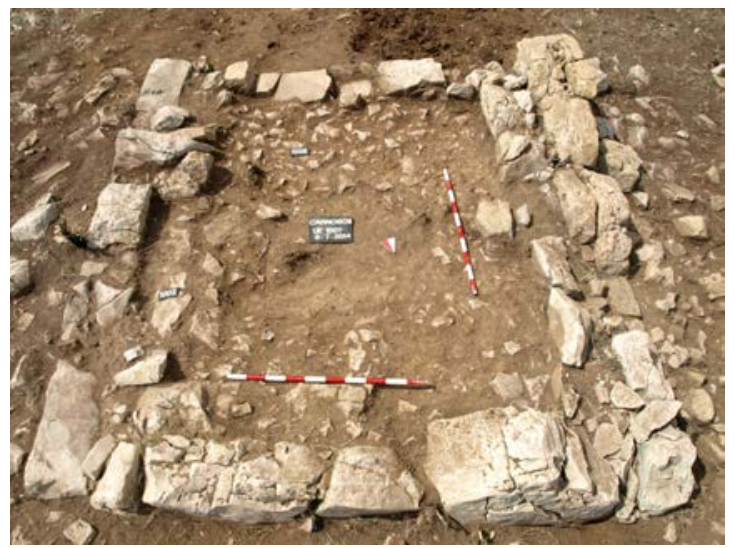

Fig. 4: Sepultura 1 durante el proceso de excavación.

en ningún momento. Curiosamente el punto que Miguel F. Aragón marca en el mapa de la ficha sí que coincide con el punto descrito por V. Llatas pero no así las coordenadas que aparecen en la ficha. La segunda ficha de Miguel F. Aragón, Corrales de Carnoso II, no ofrece ninguna duda de que se refiere al poblado amurallado situado en la margen izquierda del barranco Carnoso. Las coordenadas que aparecen en la ficha y el punto sobre el mapa topográfico coinciden perfectamente con el poblado.

Ya en 1996 el arqueólogo francés Pierre Moret vuelve a referirse al yacimiento de los Corrales de Carnoso citando al profesor J. Uroz (Moret 1996: 456).

En definitiva, las referencias bibliográficas con las que se contaba y las fichas de inventario existentes hasta el momento del hallazgo no aportaron información directa o indirecta sobre la necrópolis pero sí que nos permitieron aproximarnos a ella lo suficiente como para poder identificar las estructuras funerarias y redescubrir el yacimiento de Corrales de Carnoso de D. Vicente Llatas.

\section{SECUENCIA ESTRATIGRÁFICA}

La excavación sistemática en área abierta de los 200 $\mathrm{m}^{2}$ del sector $\mathrm{N}$ de la necrópolis ha permitido documentar una estratigrafía arqueológica muy pobre y de escasa potencia pero de gran interés que se puede agrupar en cuatro niveles. Éstos se corresponden con un único momento de ocupación y uso centrado en finales del Ibérico Antiguo y principios del Pleno (s. V a.C.) que podría haber tenido dos fases consecutivas. 
Por ahora no es posible hablar de superposición de sepulturas o diacronía, pero se ha de hacer una matización, y es que aunque los enterramientos de este sector de la necrópolis se datan en un periodo relativamente corto, s. V a.C., se observa que en los estratos más superficiales y removidos en torno a la Sepultura 1, algunos materiales cerámicos podrían ampliar el arco cronológico desde finales del s. VI a.C. hasta principios del s. IV a.C. Se trata de aspectos cronológicos que se espera precisar y concretar en próximas intervenciones con nuevos datos.

\section{NIVEL I}

El nivel superior o Nivel I es un estrato de tierra vegetal y humus, identificado en toda la superficie excavada como UE 1000 , se caracteriza por su escasa potencia, apenas algunos centímetros, de hecho, en muchas zonas ni siquiera llegaba a cubrir las estructuras tumulares y tampoco el suelo geológico. Es de color marrón oscuro, producto de la descomposición vegetal y proporciona escasos materiales, destacando entre otros, una moneda, un dinero de vellón de Carlos I de la primera mitad del s. $\mathrm{XVI}^{4}$.

\section{NIVEL II}

Subyacentes al Nivel I se identifican los estratos asociados al derrumbe y expolio de la necrópolis, UUEE 1003, 1004-1005, 1007, 2002, 2003, 2007 y 2008. La descripción de dichos estratos es la de tierra oscura y grumosa con abundantes piedras pequeñas y medianas en los que aparecen los restos humanos cremados y los escasos materiales asociados a los ajuares y las urnas cinerarias.

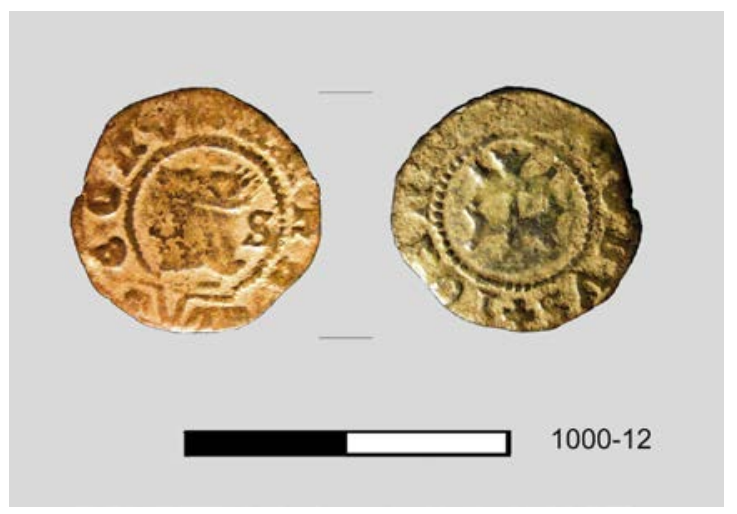

Fig. 5: Dinero de vellón, s. XVI.

\section{NIVEL III}

Por debajo de los estratos de derrumbe y expolio aparecen las tres estructuras funerarias: Sepulturas 1, 2 y 3 (UUEE 1002/1006/1008, 2001/2004/2005 y 2010/2009); los niveles de circulación (UE 1009) y la acumulación de piedras y remociones antiguas (UUEE 1010/1011/1012/1013 y 2006/2013). Estas estructuras constructivas, que en su día configuraron el paisaje funerario ibérico de El Carnoso, actualmente enormemente desfigurado, se asientan sobre estratos de preparación: rellenos de tierras rojizas y casquijo que colmata las muchas y profundas irregularidades del terreno geológico, UE 1001.

\section{NIVELIV}

Este nivel se corresponde con el suelo natural de calizas dolomíticas (UE 1001). Éstas presentan unos pliegues muy marcados, inclinados unos $45^{\circ}$ que se escalonan en su afloramiento dando una imagen muy especial al lugar. Estos pliegues tienen una orientación NO-SE, significativamente es la orientación de dos de los lados de las estructuras tumulares. Sus crestas blanquecinas forman "calles" a diferente nivel que son aprovechadas para instalar las tumbas.

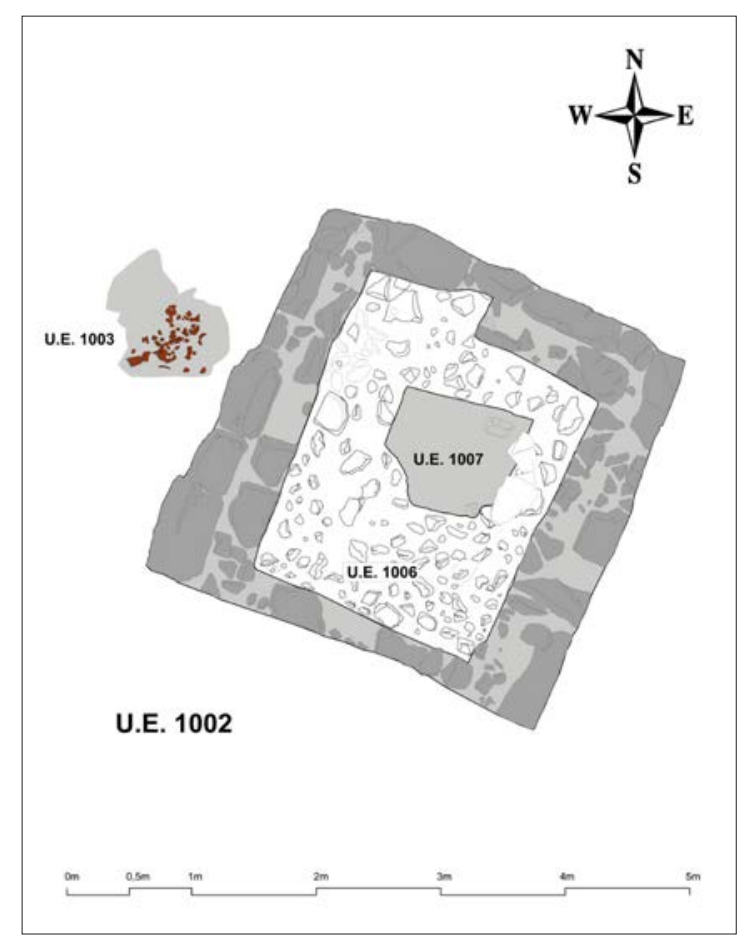

Fig. 6: Planta de la Sepultura 1 (Dibujo V. Vivó y J. M. Burriel). 


\section{LAS SEPULTURAS TUMULARES}

Para la clasificación tipológica de las sepulturas del Nivel III, tanto de las asociadas a estructuras tumulares como a las sepulturas en hoyo, se ha optado por la propuesta del profesor J. J. Blánquez (1990: 345) para todo el ámbito geográfico de la cultura ibérica, con especial atención a la zona del SE peninsular, al considerar que es una tipología de sobra conocida y claramente aplicable a la necrópolis en estudio. Según esta clasificación de las tumbas ibéricas, habría cuatro tipos y siete subtipos:

Tipo I. Simples tumbas de cremación en hoyo, con o sin urna cineraria:

Ia. Sin urna.

Ib. Con urna.

Tipo II. Tumbas de cubrición tumular, principescas o no; en piedra, adobe o tierra:

IIa. Principesca.

IIb. Sencilla con sillarejo o sillares trabajados, pero siempre de reducidas dimensiones.

Tipo III. Tumbas de cámara, con o sin corredor; individuales o colectivas:

(Propias de la zona Bastetania y Turdetania).

Tipo IV. Tumbas con sobrestructura arquitectónica, bien del tipo turriforme, bien de pilar-estela.

IVa. Turriforme.

IVb. Pilar-Estela.

\section{SEPULTURA 1}

Teniendo en cuenta las dimensiones de la Sepultura 1, UE 1002, se puede considerar del Tipo IIb de Blánquez, es decir, tumba de cubrición tumular sencilla. Se localiza al NE del área excavada y es de planta cuadrada y de dimensiones relativamente considerables: $3,13 \mathrm{~m}$ en el lado NE; 3,20 m en el lado SE; 3,07 m en el lado SO y $3,25 \mathrm{~m}$ en el lado NO. Fue levantada sobre la roca natural tras un ligero acondicionamiento del terreno. Los muros perimetrales están hechos de mampostería muy bien careada y trabada con barro. Muchas piedras, especialmente en las esquinas, son auténticos sillares. El grosor de los muros, incluso la técnica con la que se levantan es variable, por ejemplo, el muro $\mathrm{NO}$ es el más potente y el que ha conservado mayor alzado $(0,65 \mathrm{~m})$, fue construido en realidad con un doble muro cuya anchura alcanza $0,64 \mathrm{~m}$; el lado NE es de grosor irregular, de $0,65 \mathrm{~m}$ a $0,30 \mathrm{~m}$; el lado SE alcanza $0,40 \mathrm{~m}$ y el SO sólo $0,30 \mathrm{~m}$. Por lo tanto fue una estructura elevada que pudo contar con una grada y alcanzar una altura aproximada de entre $0,90 \mathrm{~m}$ y $1 \mathrm{~m}$. En su interior se habían conservado varias UUEE de relleno que permitieron analizar aspectos interesantes en cuanto a la construcción y expolio. En primer lugar se acondicionó el terreno nivelándolo parcialmente (UE 1008), al mismo tiempo que levantaban los muros perimetrales (UE 1002); a continuación fue rellenado el espacio interior (UE 1006) y se habilitó una

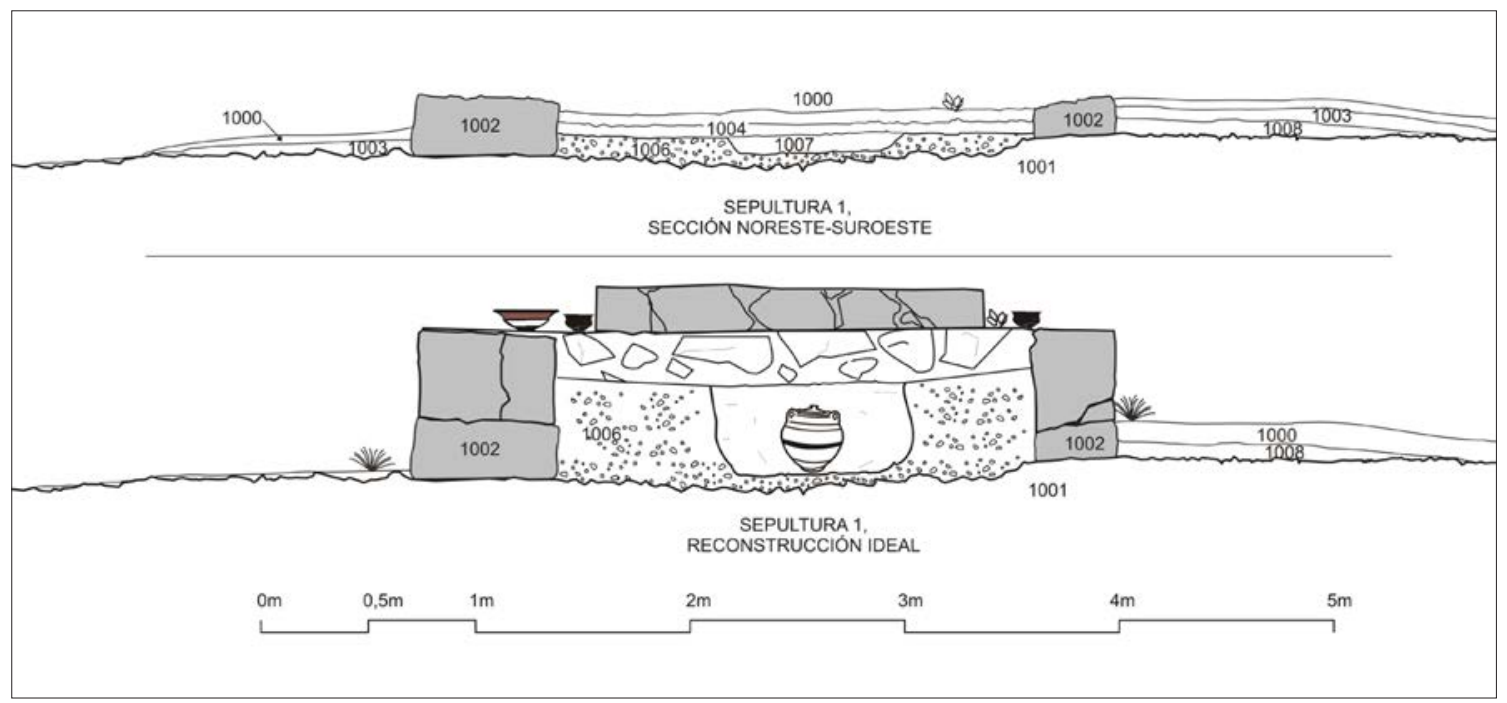

Fig. 7: Sección de la Sepultura 1 y reconstrucción ideal (Dibujo V. Vivó y J. M. Burriel). 


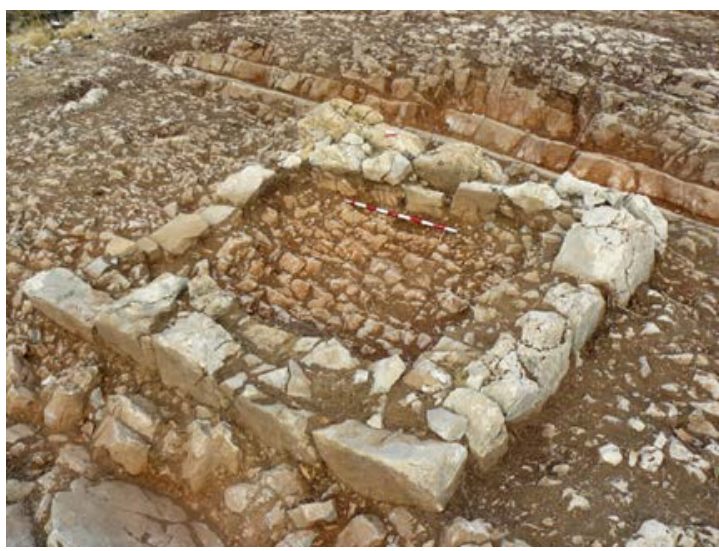

Fig. 8: Sepultura 1, UE 1002, tras su excavación.

zona de tendencia rectangular ligeramente desplazada del centro, donde presumiblemente se depositaron la urna cineraria y otros objetos cerámicos y metálicos como ajuar. Objetos que sin duda fueron expoliados y de los que aparecen algunas evidencias dispersas al exterior de la sepultura. Una vez depositados los citados objetos, ésta fue sellada, aunque no se puede descartar su posterior reutilización. Siglos más tarde la tumba fue saqueada y el receptáculo o nicho vaciado, con el tiempo este espacio se fue colmatando con la UE 1007, para finalmente depositarse la UE 1004 (tierra vegetal muy similar a la UE 1000). En cuanto a su orientación diremos que las diagonales de los vértices están dispuestas siguiendo muy aproximadamente los cuatro puntos cardinales, orientación común a otras necrópolis ibéricas, por ejemplo, la de Los Villares de Hoya Gonzalo (Albacete) (Blánquez 1990: 121 y fig. 10).

\section{MATERIALES ASOCIADOS}

Son relativamente escasos los materiales asociados: un pequeño objeto de hierro y 153 fragmentos cerámicos (151 de la UE 1003 y dos de la UE 1008). En el caso de la cerámica, siempre a torno, es de gran valor arqueológico al permitir identificar en la UE 1003, localizada al exterior de la estructura tumular, fragmentos de la urna en la que muy probablemente estuvo depositada la cremación. Para la clasificación de la cerámica ibérica se ha utilizado, siempre que ha sido posible, la tipología elaborada por C. Mata ${ }^{5}$ y H. Bonet (1992: 117-173). Por otro lado, se ha documentado abundante material antropológico en la citada UE 1003.

\section{LA CERÁMICA DE LA UE 1003}

Las formas cerámicas identificadas han sido cuatro: ánfora de imitación, tinaja, plato y tapadera.

1) Ánfora de imitación:

Es una forma definida en otras necrópolis como "jarra de dos asas". Se hallaron varios fragmentos de la boca, cuello, cuerpo y asas que muy probablemente imitan la forma de un ánfora griega. Conserva fragmentos de las dos asas que se adhieren al cuello de la pieza y al hombro, son asas con forma de "cayado", acintadas al exterior y geminadas al interior. En algunos fragmentos del borde interior de la boca se aprecian restos de pintura color rojo vinoso. La pasta es muy blanda y se raya fácilmente como consecuencia de una cocción de calidad regular. Este recipiente pudo ser la urna cineraria de la Sepultura 1 ya que sus fragmentos aparecen mezclados con los huesos humanos cremados (fig. 9, 1003-1).

2) Tinaja de borde vuelto y moldurado (tipo A.I.2.):

Es una forma muy típica de las producciones ibéricas, con abundantes paralelos en ambientes funerarios del s. V a.C. (fig. 9, 1003-2).

3) Plato de borde vuelto (tipo A.III.8.):

Como en el caso anterior son abundantes los paralelos y la mayoría remiten al s. V a.C. El borde de plato es de ala ancha y pendiente. No ha conservado la ornamentación pictórica (fig. 9, 1003-3).

4) Tapaderas (tipo A.V.1.):

Se recuperaron dos fragmentos muy pequeños de borde (fig. 9, 1003-4 y 1003-5).

\section{OBJETOS METÁLICOS}

Un pequeño fragmento de hierro (UE 1003) con forma de varilla de 1,5 cm de largo de sección cuadrada de $0,03 \mathrm{~cm}$. Muy probablemente se trata de un pequeño pasador.

\section{MATERIAL ANTROPOLÓGICO}

Este material apareció concentrado en una pequeña área del estrato UE 1003. Se exhumaron $120 \mathrm{~g}$ de restos óseos cremados pertenecientes a un sujeto adulto de sexo indeterminable.

\section{SEPULTURA 2}

Como en el primer caso, es otra sepultura expoliada desde antiguo, pero en éste las evidencias son mayores ya que en la acción de expolio se desmantela el lado NO de la estructura. Esta segunda sepultura también se puede 


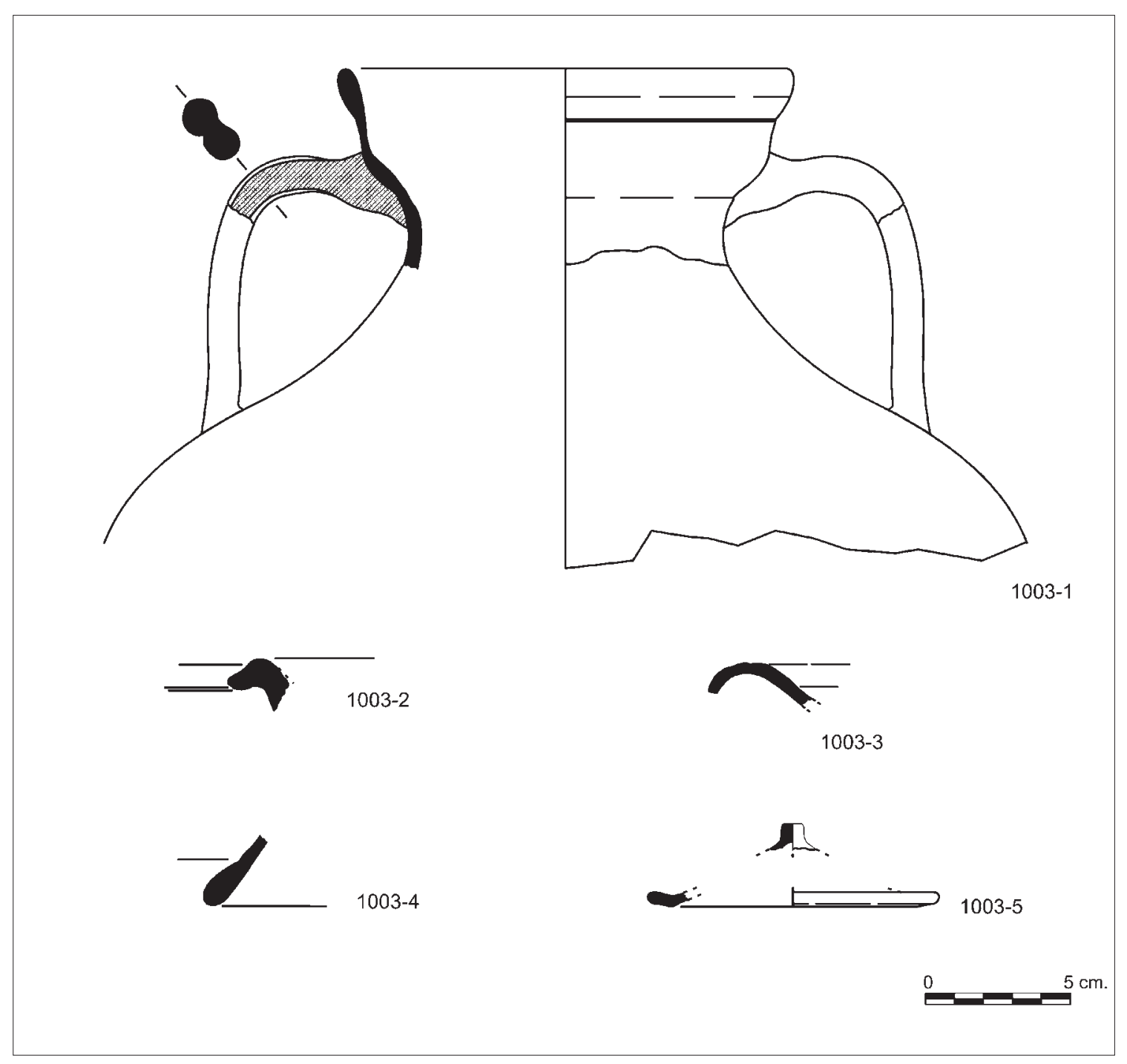

Fig. 9: Materiales cerámicos asociados a la Sepultura 1 (Dibujo P. Mas).

clasificar dentro del Tipo IIb, tumba de cubrición tumular sencilla. Se localiza a unos $10,50 \mathrm{~m}$ al O de la Sepultura 1. Es de planta cuadrada de aproximadamente 2,50 $\mathrm{m}$ de lado. Fue levantada sobre la roca natural tras el acondicionamiento del terreno. Los muros perimetrales (UE 2001) son de grosores irregulares pero simples (una sola hilada), están hechos con bloques de piedras del terreno, muy bien careados al exterior, trabados con barro y algunos tienen disposición vertical. El grosor de los muros es variable, el muro NO tiene $0,30 \mathrm{~m}$ en el punto más ancho y 0,20 m en el mínimo, siendo el que conserva mayor altura $(0,50 \mathrm{~m})$; el lado NE es de grosor irregular, de 0,50 m a 0,25 m; el lado SE es el más grueso, 0,60 m. Como la Sepultura 1, también fue una estructura elevada, exenta, muy visible pero muy posiblemente de menos altura que no superaría $0,80 \mathrm{~m}$ y posiblemente contaría con escalón superior. En su interior se han excavado varias unidades estratigráficas que permiten, reconstruir su estructura interna. Los pocos indicios apuntan que en su interior, en una zona excéntrica, se depositaron la urna cineraria y otros objetos cerámicos y metálicos como ajuar. 


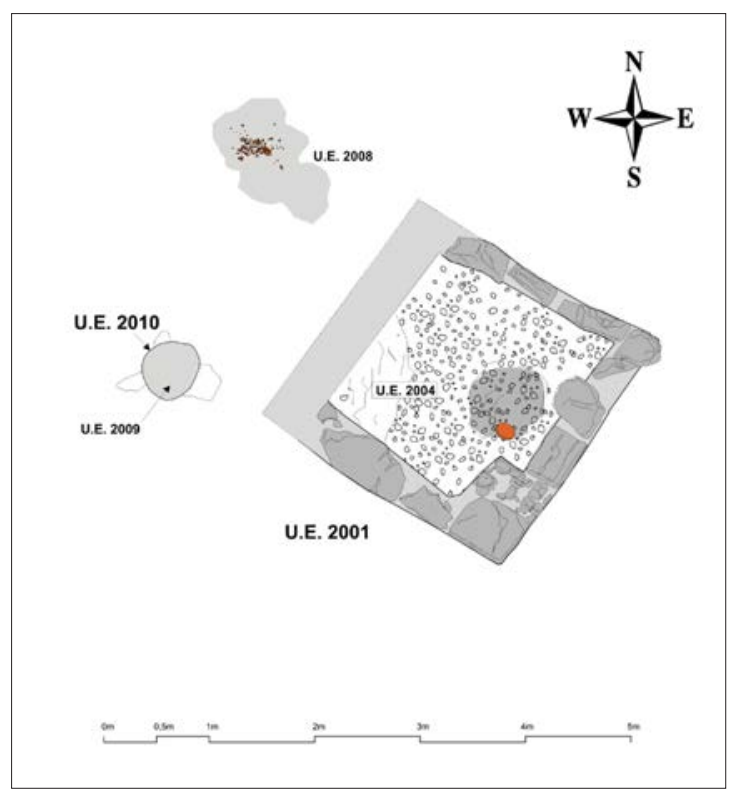

Fig. 10: Planta de la Sepultura 2 (Dibujo V. Vivó y J. M. Burriel).
Depositados la urna cineraria y los ajuares, la sepultura fue sellada, para siglos más tarde ser expoliada. Significativamente en el estrato de remoción UE 2003 (interior de la estructura) aparece una tapa de urna hecha de piedra, un disco de $16 \mathrm{~cm}$ de diámetro y de $3,5 \mathrm{~cm}$ de grosor, perfectamente recortado de una laja de piedra arenisca y un fragmento de teja moruna que delata el expolio moderno. En cuanto a su orientación geográfica, cabe decir que es idéntica a la de la Sepultura 1.

\section{MATERIALES ASOCIADOS}

Los restos materiales que se describen a continuación son relativamente abundantes si los comparamos con la Sepultura 1. Los fragmentos cerámicos recuperados son 396 (uno de la UE 2002; 216 de la UE 2003; 73 de la UE 2005; tres de la UE 2007 y 103 de la UE 2008). Son cerámicas mayoritariamente a torno de pastas claras de color beige $(96,2 \%)$, habiendo dos pequeños porcentajes de cerámica gris $(1,5 \%)$ y a mano $(2,2 \%)$.

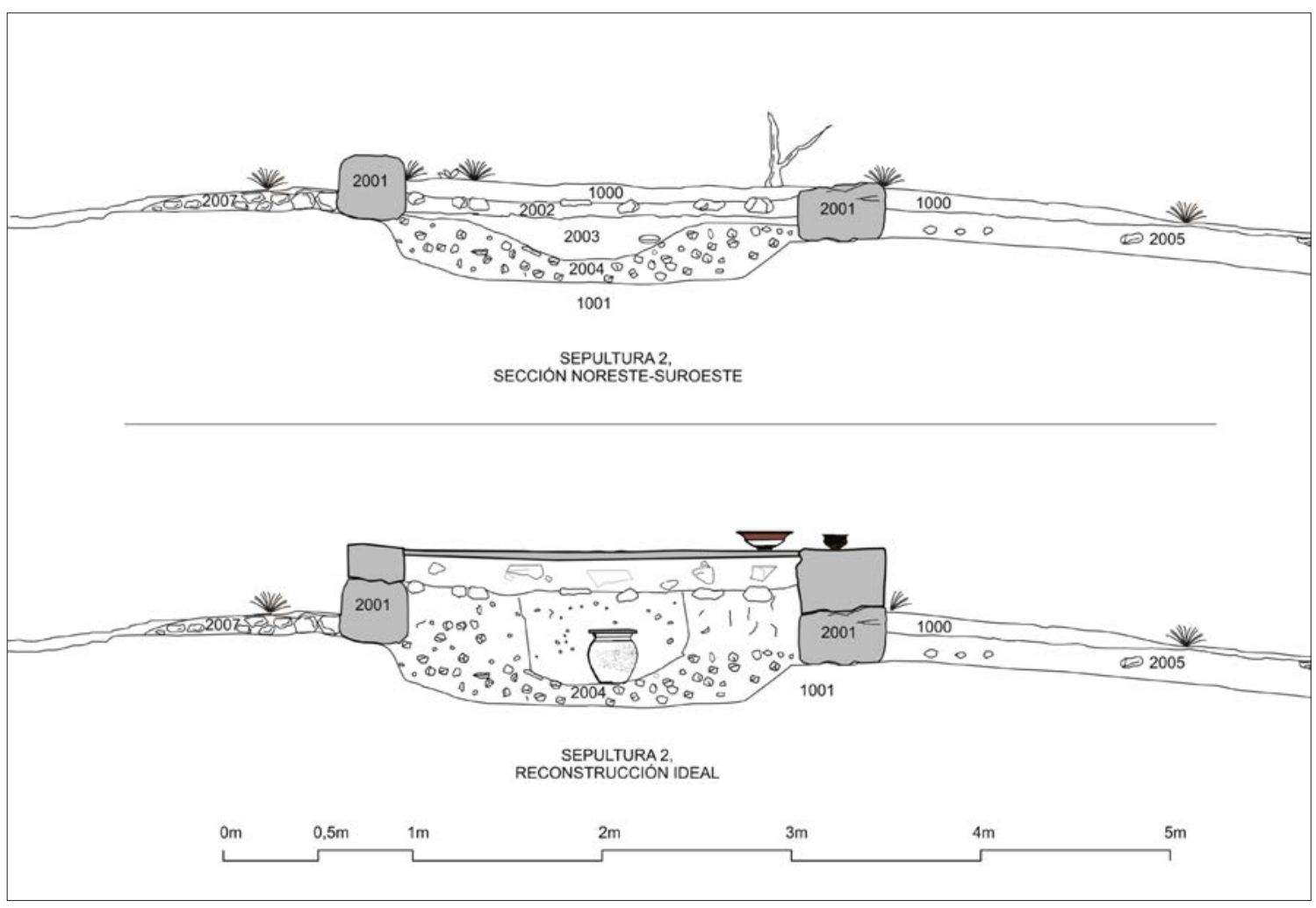

Fig. 11: Sección de la Sepultura 2 y reconstrucción idealizada (Dibujo V. Vivó y J. M. Burriel). 
También se han documentado 13 pequeños fragmentos metálicos que se distribuyen de la siguiente manera: cinco de hierro, siete de bronce y uno de plata. A todo esto se ha de sumar el material antropológico, los huesos cremados de las UUEE 2002-2003 y 2008.

\section{CERÁMICA}

Las formas cerámicas identificadas en torno a la Sepultura 2 son seis:

1) Tinaja de borde vuelto (tipo A.I.2.):

Dos ejemplares, el primero es una tinaja bitroncocónica con cuello y borde moldurado tipo "cabeza de ánade". Se observan restos de pintura muy perdidos. Está bien cocida y es una forma evolucionada al presentar una molduración del labio muy marcada. Se puede datar en los ss. V-IV a.C. Material muy típico con abundantes paralelos en ambientes funerarios ibéricos (fig. 14, 2008-1). La segunda tinaja se identifica a partir de un pequeño fragmento de borde vuelto y escasamente moldurado. Los indicios apuntan que es una tinaja de cronología antigua, s. V a.C. (fig. 14, 2008-3).

2) Tinajilla de borde vuelto (tipo A.II.2.):

También se han inventariado dos ejemplares, el primero se define como tinajilla sin hombro de borde moldurado (tipo "cabeza de ánade"). Quedan restos de pintura a bandas. Probablemente de finales del s. V a.C. -tránsito del Ibérico Antiguo al Pleno- (fig. 13, 2003-2). La segunda tinajilla presenta el borde vuelto y moldurado. También se observan restos de pintura muy perdida. Por los paralelos hallados, la pieza se data en el s. V a.C. (fig. 14, 2008-2).

3) Urna de orejetas perforadas (tipo A.I.4.):

Otros dos individuos, el primero es un fragmento de boca de urna de orejetas con una línea moldurada o baquetón de 1,5 cm en el mismo borde. Muy probablemente del s. V a.C. (fig. 13, 2003-3). La segunda urna viene representada por un apéndice perforado u "orejeta" de forma cuadrada de $2 \mathrm{~cm}$ x $2 \mathrm{~cm}$ y $1,5 \mathrm{~cm}$ de altura con agujero circular precocción. (fig. 13, 2003-4).

4) Botella (tipo A.IV.1.1.):

Se corresponde con un fragmento muy pequeño descrito en el inventario elaborado tras la intervención como una forma cerrada y de poca altura que probablemente era una botellita o cubilete. El borde está marcado con una simple moldurita curva (fig. 13, 2003-5).

5) Tapadera (tipo A.V.1.):

Se halló sólo un fragmento de borde recto (fig. 13, 2003-9).

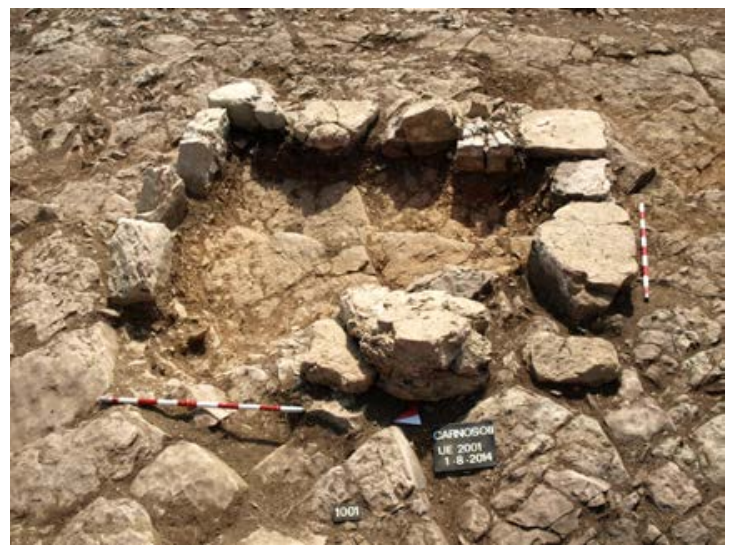

Fig. 12: Sepultura 2, UE 2001, tras el proceso de excavación.

6) Caliciforme:

De esta forma se hallaron dos fragmentos, ambos de pasta gris, el primero es un borde de la boca de perfil en S (fig. 14, 2005-1). El segundo también es un fragmento de borde ligeramente moldurado de un vaso de pequeña altura (fig. 14, 2008-4).

7) Formas indeterminadas:

Como recipientes indeterminados se han inventariado cinco bordes. Lo reducido de los mismos no permite una identificación segura. Los cinco bordes son de pastas claras (fig. 13, 2003-1, 2003-6, 2003-7 y 2003-8 y fig. 14, 2005-2).

\section{PIEDRA}

Una tapa de arenisca marrón-amarillenta recortada con forma circular de 15/16,5 cm de diámetro y $3,6 \mathrm{~cm}$ de grosor. Se observan puntos brillantes de mica y cuarzo (fig. 13, 2003-10).

\section{OBJETOS METÁLICOS}

Se inventariaron trece fragmentos. Sólo en un caso se ha identificado la forma con seguridad.

1) Hierro:

El primero, es un fragmento de lámina de hierro curvada de $2,5 \mathrm{~cm}$ de largo $x 1,3 \mathrm{~cm}$ de ancho y $0,1 \mathrm{~cm}$ de grosor. Es parte de un objeto hueco, tal vez un fragmento de lanza o contera. Es la parte del objeto donde podría haber ido insertado un astil de madera (fig. 13, 2003-12). El segundo objeto es un clavo de hierro de sección cuadrada y cabeza rectangular de $1,5 \mathrm{~cm}$ de longitud y cabeza de 0,6 cm y de cronología indeterminada (fig. 14, 2008-8). Los otros dos objetos son informes: uno identificado con una 


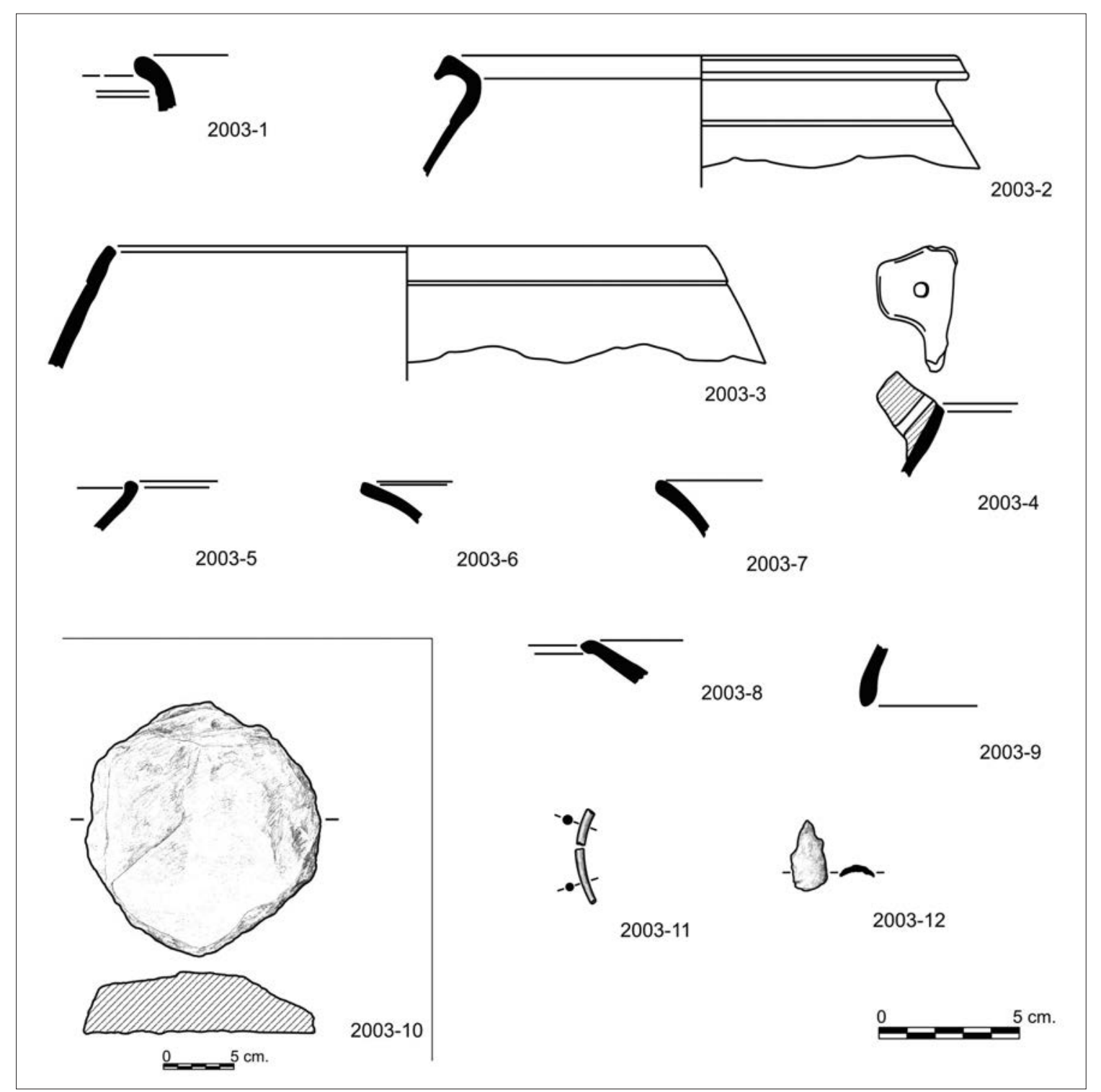

Fig. 13: Material asociado a la Sepultura 2, UE 2003 (Dibujo P. Mas).

plaquita de hierro de $3,5 \mathrm{~cm}$ de longitud, $1,5 \mathrm{~cm}$ de anchura y $0,4 \mathrm{~cm}$ de grosor (UE 2005) y otro con un fragmento informe de objeto indeterminado (UE 2005).

2) Bronce:

Se localizaron ocho pequeños fragmentos, dos en la UE 2003 y seis en la UE 2008. Los dos primeros, corresponden a una misma anilla de sección circular de $0,3 \mathrm{~cm}$, ambos fragmentos mide $1,1 \mathrm{~cm}$, tal vez se trate de una pulsera o una fíbula (fig. 13, 2003-11). En la UE 2008 se hallaron otros dos fragmentos de pulsera, uno de $1,6 \mathrm{~cm}$ de largo, 0,5 cm de ancho y sección plano-convexa, con un grosor máximo de $0,1 \mathrm{~cm}$ (fig. 14, 2008-6) y otro de $1,3 \mathrm{~cm}$ de largo por $0,8 \mathrm{~cm}$ de ancho por un grosor máximo de $0,3 \mathrm{~cm}$ (fig. 14, 2008-7). Este segundo es especialmente interesante puesto que presenta adheridos restos de huesos cremados, lo que evidencia que el individuo fue cremado con los objetos personales. Los otros cuatro fragmentos son muy pequeños: tres de varilla de bronce 


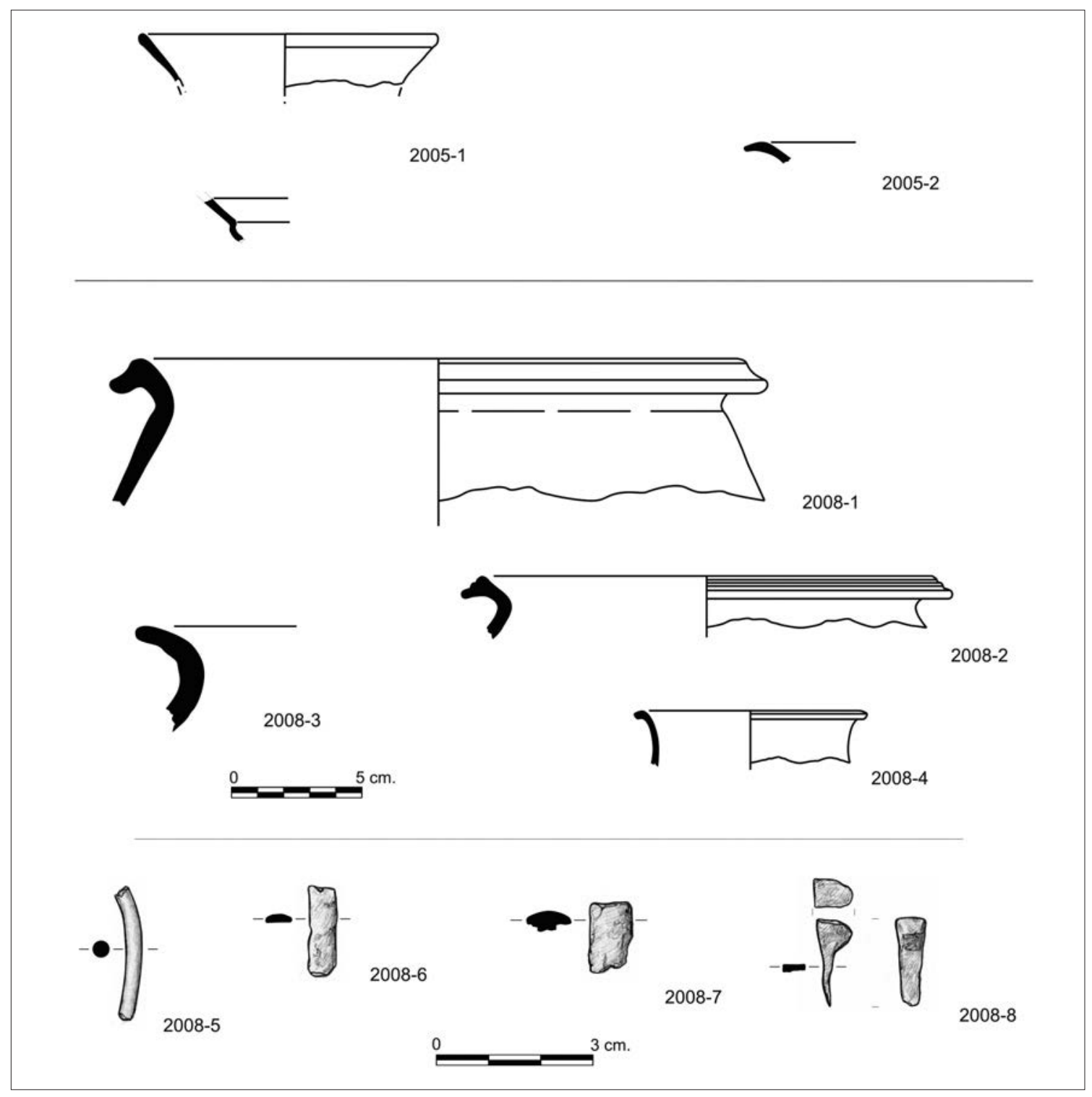

Fig. 14: Material asociado a la Sepultura 2, UU.EE 2005 y 2008 (Dibujo P. Mas).

de sección circular de $0,1 \mathrm{~cm}$ que están muy afectados por el fuego, el primero de $0,7 \mathrm{~cm}$ de longitud, el segundo de $1,5 \mathrm{~cm}$ y el tercero de $1,7 \mathrm{~cm}$. Por último se ha de citar un fragmento informe de planchita.

3) Plata.

Apareció un único fragmento de varilla cilíndrica, ligeramente curvada de $2,5 \mathrm{~cm}$ de longitud y de sección circular de $0,2 \mathrm{~cm}$ (fig. 14, 2008-5). Muy probablemente es un fragmento de pulsera o torques que formaba parte del ajuar funerario de la Sepultura 2. Los objetos de plata, sin ser muy abundantes, no son extraños en los ajuares funerarios ibéricos, por ejemplo, el torques de la necrópolis ibérica de Mianes (Tarragona) (Genera et al. 2008: 220-221 y fig. 10).

\section{MATERIAL ANTROPOLÓGICO}

Se recogieron $425 \mathrm{~g}$ de restos óseos cremados pertenecientes a un sujeto masculino adulto. No se han advertido patologías (UUEE 2003-2008). 


\section{CREMACIÓN EN HOYO}

A pesar de haberse excavado $200 \mathrm{~m}^{2}$ de la necrópolis, una superficie relativamente muy grande si la comparamos con otras excavaciones en necrópolis ibéricas, sólo se ha conservado un enterramiento de esta tipología. Esta escasa representación de cremaciones en hoyo pudo ser debida al grado de arrasamiento y remoción que sospechamos ha sufrido la necrópolis en el sector $\mathrm{N}$ a lo largo de los siglos, aunque tampoco descartamos un carácter más exclusivo de las tumbas de estructura tumular.

\section{SEPULTURA 3}

Del mismo modo que se ha empleado la tipología del profesor Blánquez para las sepulturas tumulares, también lo hemos hecho para las tumbas de cremación en hoyo, clasificándola dentro del Tipo Ia. La Sepultura 3 se localizaba a $1 \mathrm{~m}$ al $\mathrm{O}$ de la Sepultura 2. Era de planta circular de aproximadamente $0,40 \mathrm{~m}$ de diámetro por $0,15 \mathrm{~m}$ de profundidad conservada, no se observó ningún resto de superestructura ni de urna cineraria por lo que encaja bien con las sepulturas del Tipo Ia, cremación en hoyo sin urna. A diferencia de las Sepulturas 1 y 2, todo parece indicar que no hubo expolio y a lo sumo se retiró la posible señalización de la sepultura en el caso de que la hubiera tenido. El hoyo fue excavado en el estrato UE 2011, el cual rellenaba una pequeña depresión natural del terreno (UE 1001). Dentro del loculus (UE 2010) que parcialmente está en contacto con la roca natural, se depositaron los restos de la cremación UE 2009.

\section{MATERIALES ASOCIADOS}

A diferencia de las otras dos sepulturas descritas en puntos anteriores, esta tercera se puede considerar un pequeño depósito estratigráfico cerrado por lo que se analizarán los materiales por separado, es decir, por un lado el relleno UE 2009, depositado en el interior del loculus UE 2010 y por otro el estrato UE 2011 en el que se excavó el citado loculus.

\section{UE 2009-2010}

El relleno UE 2009 era de tierra oscura, prácticamente negra, producto de los restos de la cremación del cadáver. En él se recogieron 19 fragmentos de cerámica ibérica, 78 fragmentos de bronce, que se corresponden con un mínimo de tres pulseras o brazaletes muy deteriorados (figs. 16 y 17) y $290 \mathrm{~g}$ de fragmentos y esquirlas de huesos humanos cremados.

\section{Cerámica}

Sólo se ha identificado una forma, la de un posible vaso caliciforme de pasta gris. A esta forma de cerámica se han de sumar cinco fragmentos más de clase A y 12 de clase B.

1) Forma caliciforme:

Es un fragmento de borde de un pequeño vaso caliciforme de pasta gris a torno con la pasta muy depurada (fig. 17, 2009-1).

2) Forma indeterminada:

Como recipiente indeterminado se ha inventariado un borde exvasado de cerámica tosca o de clase B. Lo reducido de los mismos no permite una identificación formal clara (fig. 17, 2009-2).

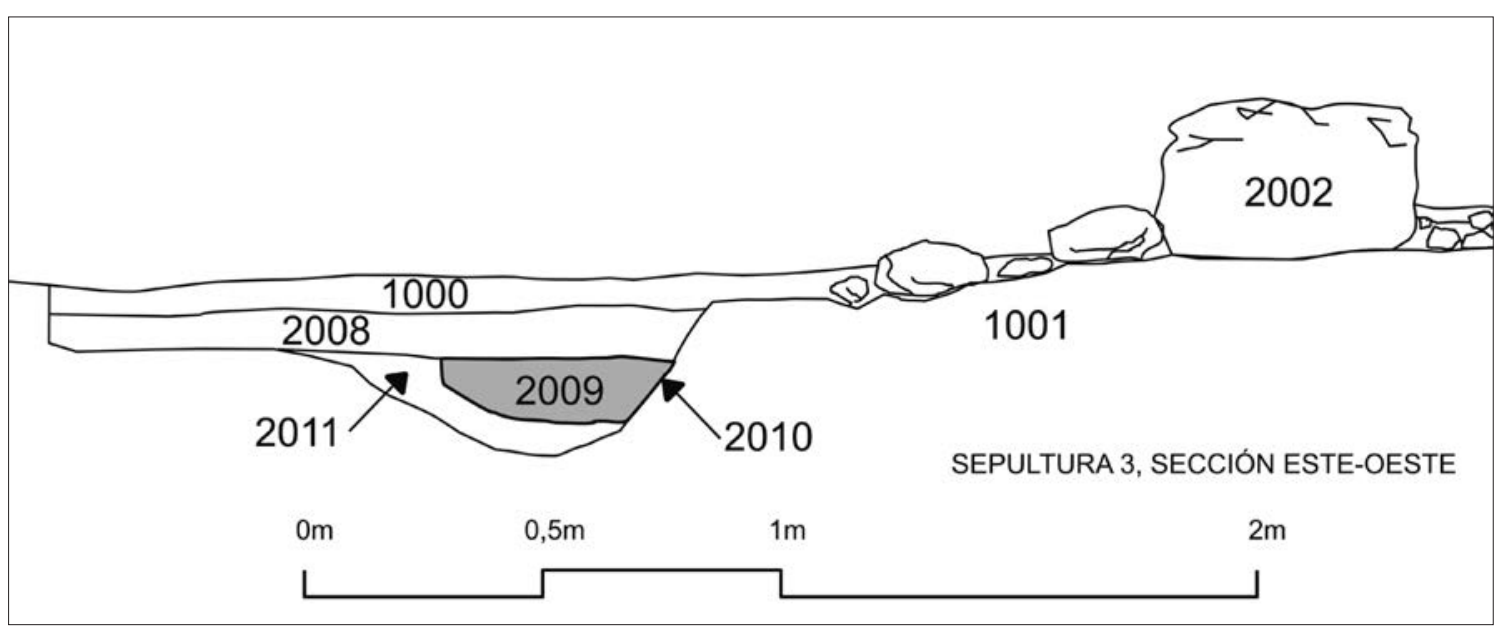

Fig. 15: Sección de la Sepultura 3, UE 2010 (Dibujo V. Vivó y J. M. Burriel). 

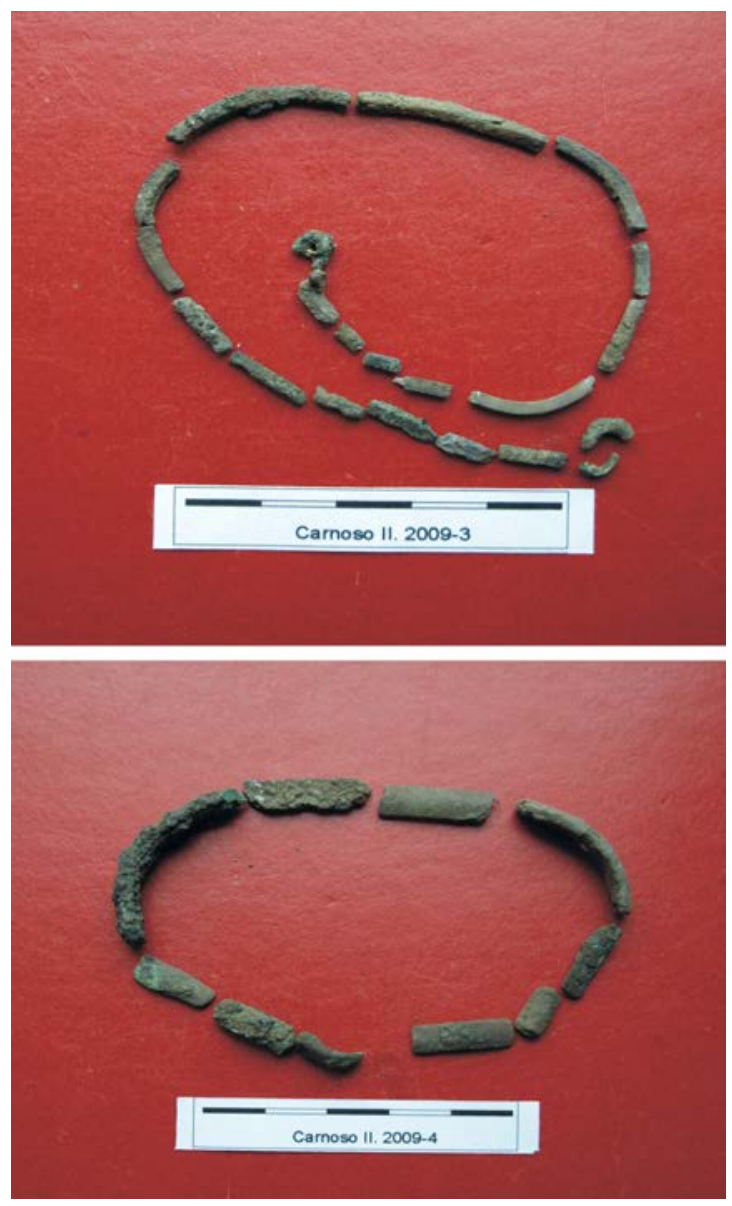

Fig. 16: Ajuar de la Sepultura 3, 2009-3 y 2009-4.

\section{Objetos metálicos}

Se recuperaron 78 pequeños fragmentos que se distribuyen de la siguiente forma:

1) Bronce:

Un brazalete o pulsera abierta de 19 fragmentos de alambre de sección cuadrada $(0,3 \mathrm{~cm})$. Dos de estos fragmentos están enroscados y podrían ser enganches o cierres. El pequeño tamaño de los 19 fragmentos dificulta enormemente poder determinar cuál sería su diámetro real. Estos brazaletes a veces aparecen formando conjuntos múltiples de diámetro decreciente para ajustarse al antebrazo (figs. 16-17, 2009-3). Una pulsera ovalada de bronce de la que se conservan diez fragmentos de sección plano-convexa (media caña). Diámetro máximo interior $6,5 \mathrm{~cm}$ y mínimo $4,3 \mathrm{~cm}$. Presenta una especie de apéndice que podría ser enganche o cierre (figs. 16-17, 2009-4). Un fragmento de pequeña pulsera

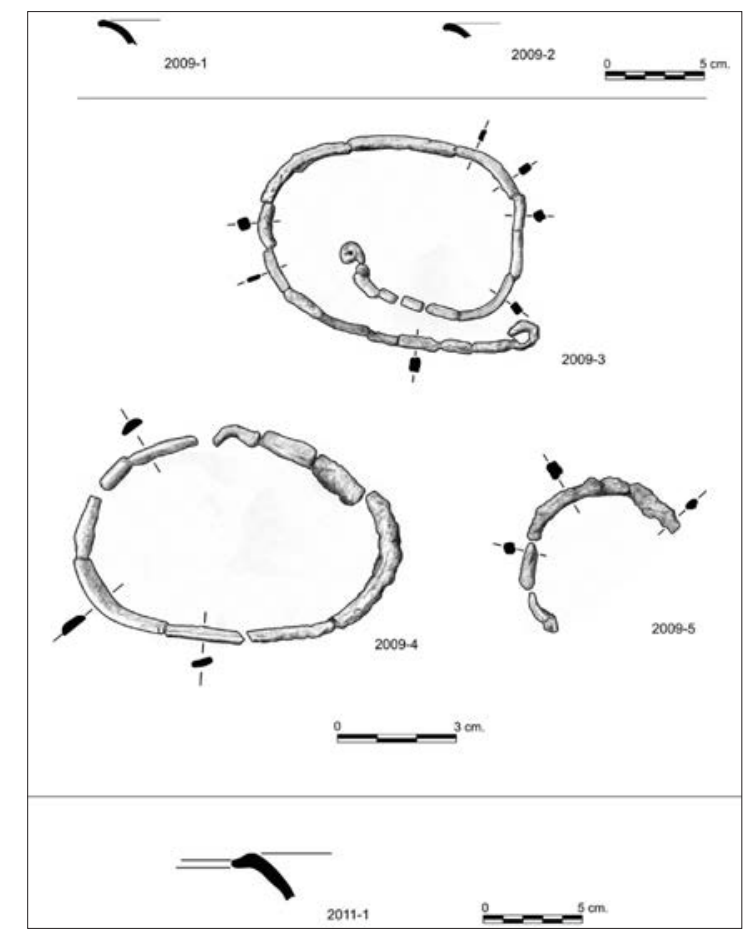

Fig. 17: Ajuar de la Sepultura 3, UE 2009 y material de la UE 2011 (Dibujo P. Mas).

de bronce de la que se conservan cuatro trozos de sección cuadrada de $0,2 \mathrm{~cm}$ de diámetro indeterminado, en él se aprecia que ha estado expuesto al fuego (fig. 17, 2009-5). Por último, en la UE 2009, 45 fragmentos informes de esquirlas de metal.

\section{Fauna}

Se exhumó un interesante metatarso proximal izquierdo de oveja (Ovis aries).

\section{Material antropológico}

Se ha recogido la totalidad de los restos óseos cremados, $295 \mathrm{~g}$ pertenecientes a un sujeto adulto de edad madura (entre 40-60 años) de sexo indeterminable. No se han advertido patologías (UE 2009).

\section{UE 2011}

\section{Cerámica de Clase A}

Se inventariaron 36 fragmentos de cerámica, mayoritariamente a torno, 13 de clase A, 14 de clase B, siete de cerámica gris y dos hechos a mano. Sólo se ha identificado una forma, un borde de tinajilla (tipo A.II.2.2.). Se trata de un borde subtriangular poco moldurado de una tinajilla hecha a torno, de pasta anaranjada y típica de los ss. V-IV a.C. (fig. 17, 2011-1). 


\begin{tabular}{|c|c|c|c|c|}
\hline & Forma & Metal & N.M.I. & $\%$ total ind. \\
\hline 1 & Clavo (de broche) & Bronce & 1 & 9,09 \\
\hline 2 & Aguja & Bronce & l & 9,09 \\
\hline 3 & Pulsera/torques & Bronce/Plata & 7 & 63,64 \\
\hline 4 & Contera $(i ?)$ & Hierro & 1 & 9,09 \\
\hline 5 & Clavo & Hierro & 1 & 9,09 \\
\hline & 56 frags. Indet. & Hierro/Bronce & & \\
\hline \multicolumn{3}{|c|}{ TOTAL } & 11 & 100 \\
\hline
\end{tabular}

Fig. 18: Tabla 1. Conjunto de tipos metálicos.

\section{Informes de pasta gris}

Siete fragmentos informes de cerámica ibérica gris, alguno de ellos podría ser de un caliciforme (UE 2011).

\section{OTROS NIVELES: UUEE 1009, 1010/1011/1012/1013}

En este punto se analiza un conjunto cerámico producto de antiguas remociones. Sin duda es el más importante y numeroso recuperado durante la campaña: 536 fragmentos que corresponde a un mínimo de 25 piezas. Un conjunto de material producto de procesos postdeposicionales de difícil interpretación pero que de forma indirecta nos podría estar indicando que hubo otras tumbas antes de ser construidas las Sepulturas 1 y 2. Como en los conjuntos anteriores, analizaremos por separado las diferentes producciones cerámicas y los distintos objetos metálicos.

\section{LA CERÁMICA DE CLASE A}

Se han inventariado y catalogado siete formas cerámicas:

1) Tinaja de borde vuelto (tipo A.I.2.):

Dos individuos, el primero es un fragmento muy pequeño de borde vuelto y moldurado (fig. 21, 1010-2).

\begin{tabular}{|c|c|c|c|c|}
\hline & Tipo & frags. & N.M.I. & \% total ind. \\
\hline 1 & Ánfora & 1 & 1 & 4 \\
\hline 2 & Tinaja de borde vuelto & 2 & 2 & 8 \\
\hline 3 & Urna de orejetas & 44 & 6 & 24 \\
\hline 4 & Plato & 10 & 5 & 20 \\
\hline 5 & Mortero & 2 & 1 & 4 \\
\hline 6 & Tapadera & 5 & 3 & 12 \\
\hline 7 & Caliciforme & 3 & 3 & 12 \\
\hline 8 & Orza de clase B & 10 & 4 & 16 \\
\hline \multicolumn{2}{|c|}{} \\
\hline
\end{tabular}

Fig. 19: Tabla 2. Formas cerámicas a torno, clases A y B, del conjunto UUEE $1009,1010 / 1011 / 1012 / 1013$.
El segundo, es un borde de tinaja con la típica moldura de cabeza de ánade, pero poco marcada. La pasta es homogénea y blanda (fig. 21, 1011-1).

2) Urnas de orejetas (tipo A.II.4.1.2):

Significativamente es la forma cerámica más representada, no sólo de este conjunto sino de toda la necrópolis. Se ha inventariado seis individuos ${ }^{6}$, tres en la UE 1009 y otras tres en la UE 1013. El primero se corresponde con 38 fragmentos de cerámica a torno de pasta blanda de cocción irregular de color beige y que se raya con mucha facilidad. Se aprecian restos de decoración muy perdida en rojo vinoso. Presenta un asa geminada adherida a la orejeta, muy típica de necrópolis ibéricas de la costa, por ejemplo: La Solivella (Alcalà de Xivert) (Fletcher 1965) o La Oriola (Amposta) (Esteve 1974) (fig. 20, 1009-1). El segundo es un pequeño fragmento de tapadera con el borde engrosado y biselado (fig. 20, 1009-6). El tercero es un asa geminada, ondulada, probablemente de urna de orejetas, pero también podría ser una tinajilla de boca moldurada (fig. 20, 1009-7). El cuarto se corresponde con dos fragmentos: uno de asa geminada adherida a la orejeta de forma rectangular con perforación precocción y de pasta color beige oscuro y un fragmento de tapa, muy probablemente de la misma urna. La pasta es blanda, típica de recipientes del ibérico antiguo (fig. 22, 1013-1). El quinto ejemplar, viene representado por un pequeño fragmento de borde de tapa biselado de pasta grisácea (fig. 22, 1013-2). El sexto se trata de un asidero de urna o tinaja de forma geminada y ondulada. Hay ejemplos en la necrópolis de La Solivella de Alcalá de Xivert (Fletcher 1965, 21, fig. 10) y en la de El Molar, San Fulgencio-Guardamar del Segura, (Monraval 1992, 40) (fig. 22, 1013-3).

3) Tapadera (tipo A.V.1.):

Se identificaron tres individuos de borde recto, dos en la UE 1009 y uno en la UE 1013. El primero a partir de tres fragmentos de borde que presenta una pasta beige muy blanda (fig. 20, 1009-5). El segundo es un borde recto, también de pasta blanda de cocción irregular (fig. 20, 1009-8). El tercer ejemplar es otro borde recto muy similar a los anteriores (fig. 22, 1013-4).

4) Ánfora (tipo A.I.1.):

Se halló un único ejemplar que se catalogó como un fragmento de boca de ánfora de borde moldurado, marcado o engrosado de pasta homogénea y blanda (fig. 20, 1009-3).

5) Plato (tipo A.III.8.):

Cinco individuos: dos en la UE 1009, uno en la UE 1011, un cuarto en la UE 1012 y el quinto en la UE 
Fig. 20: Materiales de la UE 1009 (Dibujo P. Mas)

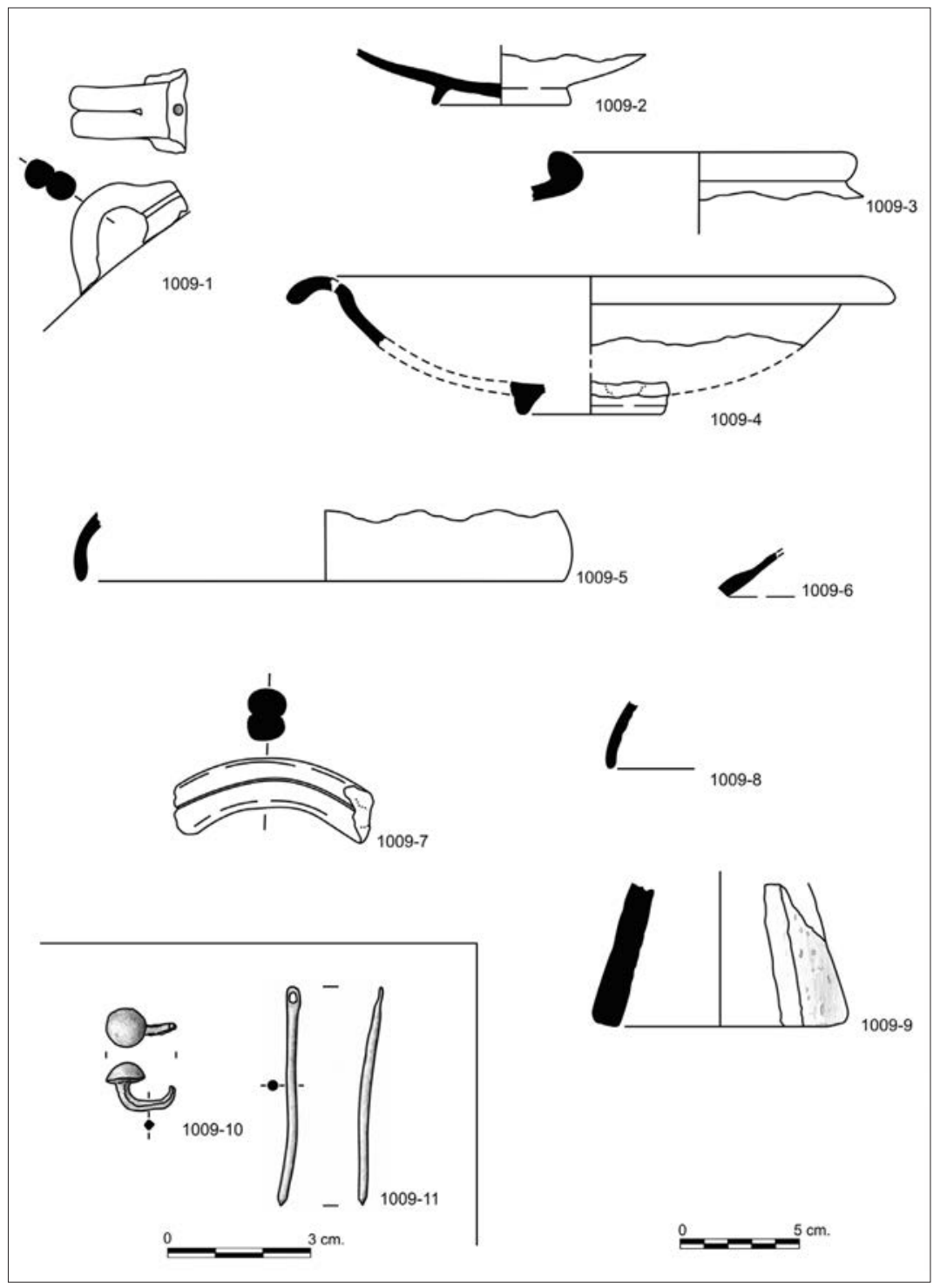

1013. El primero lo identificamos como plato a partir de tres fragmentos del pie anillado. Tiene la pasta beige y blanda, es decir, de cocción irregular. No descartamos que se hubiera utilizado como una tapadera de urna (fig. 20, 1009-2). Del segundo individuo se conservan tres fragmentos que han permitido reconstruir el perfil completo. Tiene aproximadamente $25 \mathrm{~cm}$ de diámetro exterior por $6 \mathrm{~cm}$ de altura y también la base anillada. El borde es exvasado de ala curva, con agujeros de suspensión, la pasta es de color gris-verdoso, tiene aspecto arcaico y podemos encontrar paralelos del s. V a.C. en La
Solivella, Alcalà de Xivert (Fletcher 1965, 24, fig. 12: 26 y 30; 27, fig.18: 23 y 27) y en La Mina, Gátova (Aranegui 1981, 278, fig. 7). Conserva restos de pintura roja a base de bandas y como en el caso anterior, no se descarta que se utilizara como tapa de urna (fig. 20, 1009-4). El tercer plato también presenta un perfil parecido, aunque de esta pieza sólo se conservan dos fragmentos y no ha sido posible reconstruir su perfil completo. Se describe como plato de borde curvo y ligeramente colgante al exterior; en el interior el borde está marcado por una moldura como en otros platos 


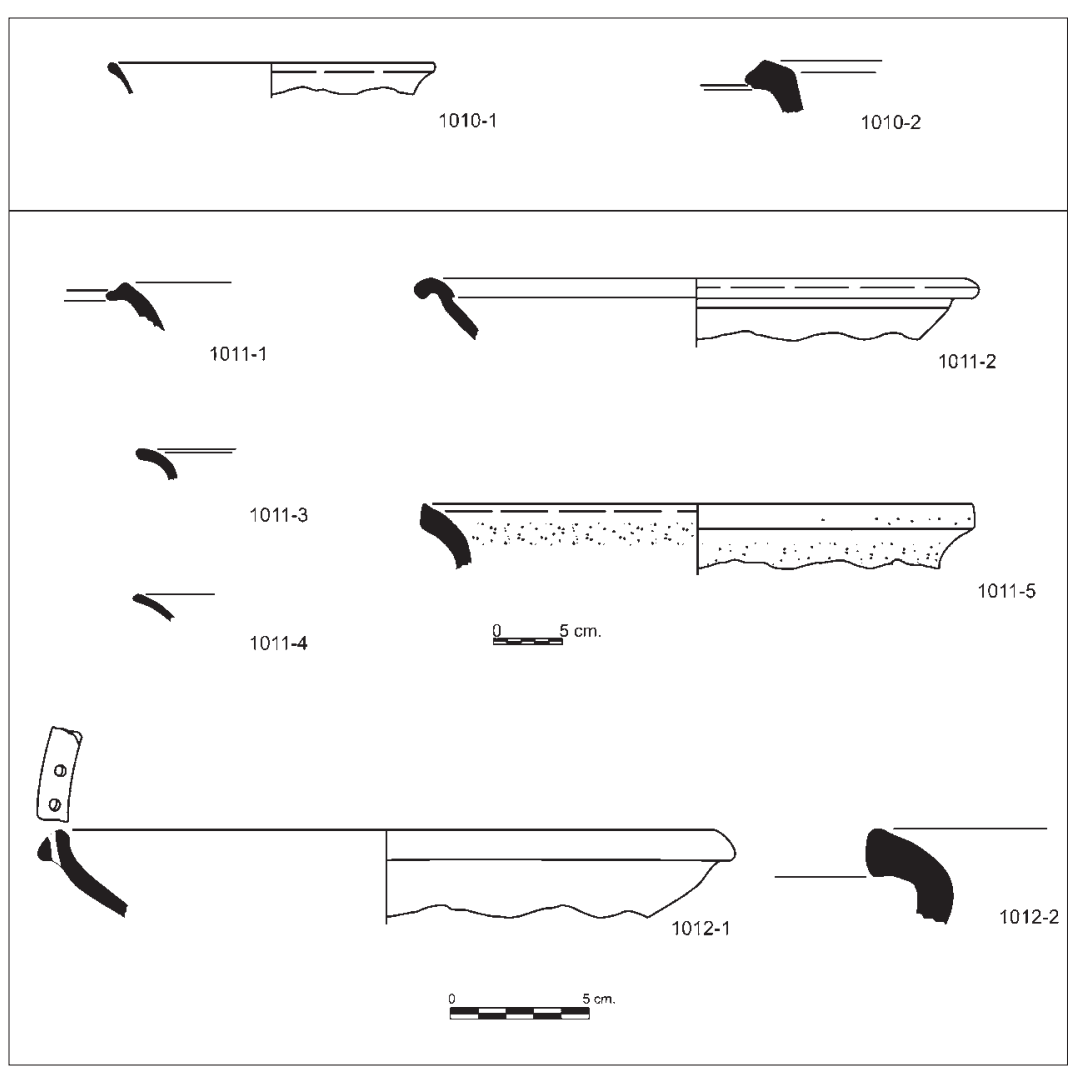

Fig. 21: Material cerámico de las UUEE 1010, 1011 y 1012 (Dibujo P. Mas).

ibéricos y protoibéricos de borde vuelto o exvasado y no conserva decoración (fig. 21, 1011-2). El cuarto es un fragmento de borde de un plato-mortero que no conserva pintura ornamental y tiene dos perforaciones precocción para colgar. (fig. 21, 1012-1). Por último, señalar un quinto plato-mortero que presenta el borde ligeramente colgante al exterior y reentrante al interior. (sección en T) (fig. 22, 1013-5).

6) Caliciforme (tipo A.III.4.):

Se recogieron fragmentos cerámicos de como mínimo cuatro individuos, tres de pasta beige y otro gris (el último es dudoso). El primero es un pequeño fragmento de borde de pasta clara en el que se observan indicios de haber sido quemado (fig. 21, 1010-1). El segundo es un borde exvasado, muy probablemente de un caliciforme de superficies de color beige pero de pasta interior gris (fig. 21, 1011-3). El tercero es un diminuto fragmento de borde de vaso caliciforme de pasta gris al interior pero de superficies beige (fig. 21, 1011-4). El cuarto posible caliciforme es también de pasta gris, se registró en la UE 1013, dentro del grupo o producción de cerámica ibérica gris.

\section{7) Mortero:}

La forma de mortero ibérico se identifica a partir de dos fragmentos del cuerpo de un individuo. Ambos presentan en el fondo interior una espiral incisa. Hay paralelos de esta forma en el yacimiento costero de El Tòs Pelat de Moncada (s. VI-IV a.C.) (Burriel y Mata 2013, 93 : 1344-1) y en algún otro yacimiento de la comarca de la Serranía (hasta ahora inédito), por ejemplo, en el Castellar (Aras de los Olmos), Masada Mosén (Higueruelas), Hoya de Antaño I y Cerro de los Pascualillos de Calles (fig. 22, 1013-6).

\section{CLASE B}

Se cuenta con una sola forma cerámica: Orza (tipo B.1.1.).

Esta producción se caracteriza por presentar superficies negras con abundante desgrasante. Son cuatro los individuos identificados. El primero, está representado por cinco fragmentos de la boca de un gran recipiente contenedor que pudo haber servido de urna cineraria. Aparecen restos de la misma pieza en las UUEE 1012 y 1013. Esta dispersión del material sugiere una 
Fig. 22: Material cerámico de la UE 1013 (Dibujo P. Mas).

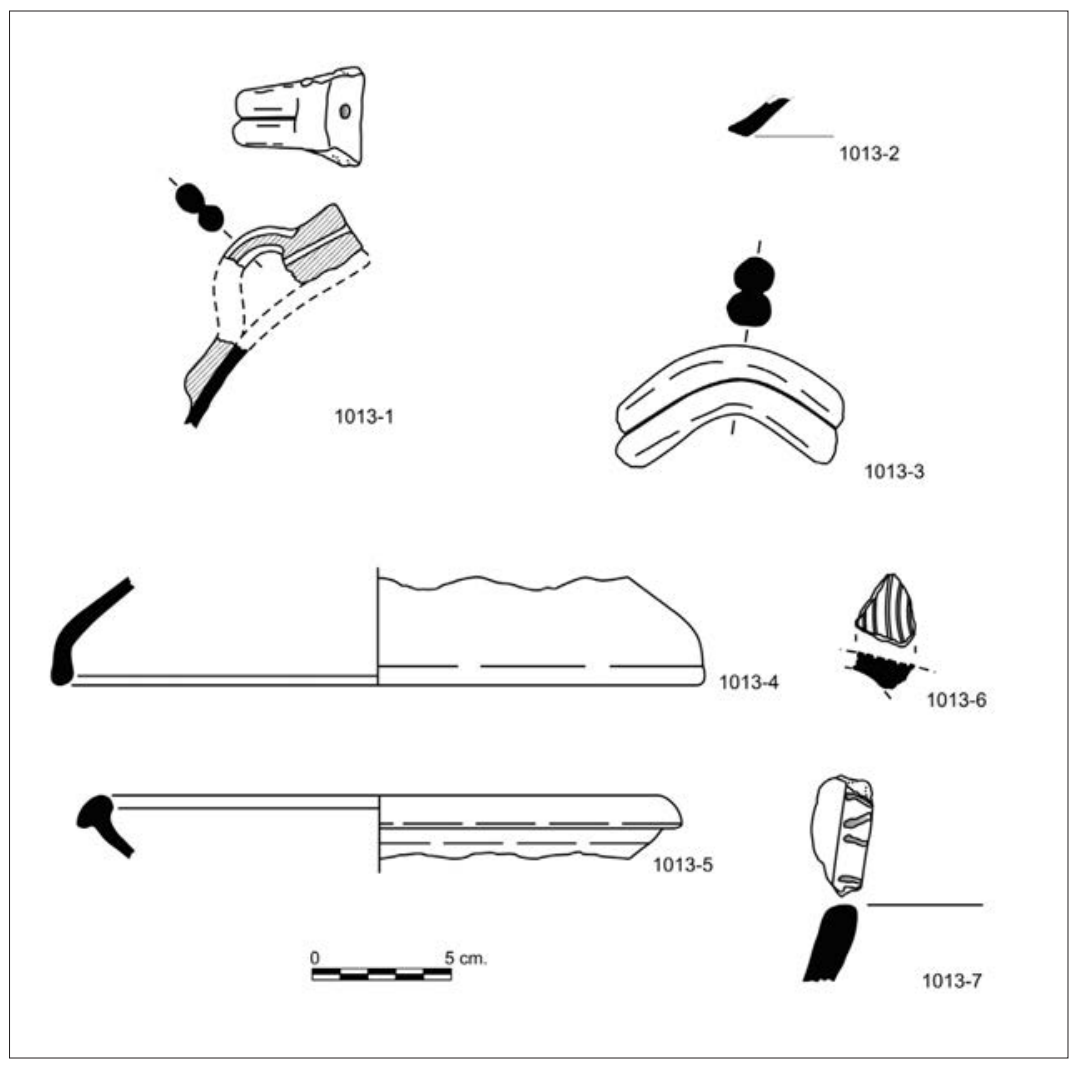

remoción estratigráfica muy significativa (fig. 21, 1011-5). En la UE 1012 se han inventariado otras dos orzas de las que sólo se dibuja una. Presenta pasta negra con abundante desgrasante cálcico (fig. 21, 10122). Por último, se inventarió un fragmento de una gran orza de borde recto con varias incisiones en el borde (fig. 22, 1013-7).

\section{CERÁMICA GRIS}

De esta producción se hallaron dos fragmentos informes en la UE 1013 de los que resulta imposible saber a que forma pertenecen.

\section{CERÁMICA A MANO}

Se inventariaron 63 fragmentos de cerámica a mano, casi el $100 \%$ en la UE 1009. Excepto dos, todos son informes y no permiten identificar ninguna forma concreta. La excepción, 1009-9, podrían ser parte de una base calada de un recipiente utilizado como urna, aunque no descartamos otros usos. De ser esta forma cerámica, sería material residual del Bronce Final-Hierro I. Son recipientes que en la zona catalana se les denominan peus reixats o peus calats y pueden aparecer en contextos funerarios (Rafel 1998). También se ven abundantes vacuolas en la superficie de la pasta (fig. 20, 1009-9).

\section{OBJETOS METÁLICOS}

Se exhumaron cinco pequeños elementos metálicos, cuatro de ellos en la UE 1009 y uno en la UE 1010: dos de hierro y tres de bronce. Sin duda son restos de objetos metálicos depositados como ajuar funerario en sepulturas destruidas o que formaban parte de la vestimenta de los individuos cremados.

1) Bronce.

Se halló un interesante clavo de bronce de cabeza hemiesférica de 0,6 cm de diámetro y punta corta de sección cuadrada, de 1,3 cm de longitud que aparece doblada $90^{\circ}$. Casi sin duda se trata de un clavo de los que sujetan los broches de garfios de bronce en los cinturones de cuero (fig. 20, 1009-10). Una aguja completa de bronce, perfectamente conservada que tiene $4,7 \mathrm{~cm}$ de longitud y sección circular de $0,2 \mathrm{~cm}$. El ojal es cuadrangular casi ovalado y aplanado y la punta facetada (fig. 20, 1009-11). Por último, una planchita de bronce de forma 


\begin{tabular}{|c|c|c|c|c|}
\hline & Forma & Tipologia & N.M.I. & \% total ind. \\
\hline 1 & Ánfora de imitación & A.VI. & 1 & 1,82 \\
\hline 2 & Ánfora & A.I.1 & 3 & 5,45 \\
\hline 3 & Tinaja de borde vuelto & A.I.2. & 8 & 14,55 \\
\hline 4 & Tinajilla de borde vuelto & A.II.2. & 4 & 7,24 \\
\hline 5 & Urna de orejetas & A.I.4 & 8 & 14,56 \\
\hline 6 & Plato & A.III.8 & 6 & 10,91 \\
\hline 7 & Mortero & A.V.4 & 1 & 1,82 \\
\hline 8 & Tapadera & A.V.1 & 9 & 16,36 \\
\hline 9 & Caliciforme & gris/clara & 6 & 10,91 \\
\hline 10 & Botella & A.IV.l.l. & 1 & 1,82 \\
\hline 11 & Orza (clase B) & B.I.1. & 5 & 9,09 \\
\hline 12 & Indeterminada & p. clara & 3 & 5,45 \\
\hline TOTAL & & $\mathbf{5 5}$ & $\mathbf{1 0 0}$ \\
\hline
\end{tabular}

Fig. 23: Tabla 3. Conjunto de todas las formas de cerámicas (N.M.I., número mínimo de individuos).

triangular de $2 \mathrm{~cm} \times 2,2 \mathrm{~cm} \times 2 \mathrm{~cm}$ y $0,05 \mathrm{~cm}$ de grosor que se recogió en la UE 1010.

2) Hierro.

Una planchita de hierro de forma cuadrangular de 0,2 $\mathrm{cm}$ de grosor y $1,7 \mathrm{~cm}$ de largo x 1,6 cm de ancho y un fragmento o nódulo de hierro informe. Ambos se recuperaron en la UE 1009.

\section{FAUNA}

En la UE 1009 se han identificado dos fragmentos de diáfisis y un fragmento de epífisis de meso mamífero indeterminado y en la UE 1011 un molar tercero inferior derecho incompleto de un bovino (Bos taurus).

\section{LA NECRÓPOLIS DE EL CARNOSO II EN SU CONTEXTO CULTURAL}

Las necrópolis ibéricas con estructuras tumulares abarcan un área geográfica muy amplia que está más o menos bien delimitada y que se conoce como "Área del Sureste", provincias de Valencia, Alicante, Murcia, Albacete, Cuenca, Toledo y Alta Andalucia. Estas necrópolis, además de las estructuras tumulares (cuadradas y rectangulares), siempre cuentan con enterramientos del tipo Ia y Ib de Blánquez, es decir, cremaciones en hoyo.

Los paralelos más próximos al Carnoso $\mathrm{II}^{7}$ se localizan en la necrópolis de los Corrales de la Nava (Castelfabib), todavía en la Comunidad Valenciana, concretamente en la comarca del Rincón de Ademuz. En esta necrópolis se documentó en 1985 una tumba de cubierta tumular
(Aparicio 1991, 182) del Tipo IIb de Blánquez. Según el informe publicado existen en el yacimiento otras tumbas de las mismas características que siguen soterradas. La estructura tumular excavada por el Servicio de Investigación Prehistórica de la Diputación de Valencia, institución provincial a la que pertenecía J. Aparicio Pérez, debió ser cuadrangular de 2,40/50 m de lado, significativamente de idénticas dimensiones que la Sepultura 2 (UE 2001) de El Carnoso II. Esta gran similitud formal de la Tumba $n^{\circ} 1$ de Los Corrales de la Nava con la de El Carnoso II no nos sorprende dada la proximidad, $59 \mathrm{~km}$ en dirección O. En cuanto a la cronología, teniendo en cuenta el tipo de urnas cinerarias exhumadas, la necrópolis de Los Corrales de la Nava podría estar centrada en el s. V a.C., la misma que por ahora asignamos a la la de El Carnoso II. En cuanto a la orientación de la T. $\mathrm{n}^{\circ} 1$ de este cementerio, cabe decir que los lados siguen la de los cuatro puntos cardinales, lo que difiere de la orientación de El Carnoso II. Por último, en las conclusiones, J. Aparicio hace una muy oportuna referencia a El Corral de Saus (Moixent) como ejemplo de necrópolis ibérica con estructura tumulares: Con respecto a la necrópolis (Corrales de la Nava) poco podemos añadir. Su estructura tumular sobre base cuadrangular no es excesivamente frecuente en la Comunidad Valenciana, dada la situación de lo conocido, aunque tampoco es extraña, recordemos el Corral de Saus entre otros (Aparicio 1991, 184). Otro detalle destacable es la no localización de escultura.

Más al O, concretamente en la Serranía de Cuenca y provincia de Toledo, territorio cuya conexión física y a través de antiguos caminos con la Serranía valenciana es más que evidente, existe otro interesante conjunto de necrópolis tumulares ibéricas. Muy significativamente en todas ellas encontramos paralelos con la necrópolis andillana pero haremos hincapié sólo en tres: las conquenses de Los Canónigos (Arcas del Villar), Cerro de la Virgen de la Cuesta (Alconchel de la Estrella) y la toledana de Palomar de Pintado (Villafranca de los Caballeros).

En el caso de Los Canónigos, y según lo publicado, se han documentado varios tipos de sepulturas de los que cabe destacar el cuarto tipo. Éste se define como estructuras tumulares realizadas con mampostería que están orientadas casi en el sentido de los puntos cardinales, con unas dimensiones medias ligeramente superiores al metro de lado (Quesada y Valero 2012, 352). De entre las publicadas destaca la Tumba 1, un pequeño túmulo cuadrangular de poco más de 1,20 m de lado que emplea piedras junto a restos escultóricos pertenecientes 
a una primera fase de uso del cementerio que no ha sido documentada en la excavación (Valero 2010, 164; 2012, 178), sepultura que podría encuadrarse dentro del Tipo IIa de Blánquez. En relación a El Carnoso II cabe destacar varias similitudes, por un lado las propias estructuras tumulares, su técnica constructiva de doble muro y su tamaño, así como su orientación, especialmente en el caso de la Tumba 1 en la que las diagonales coinciden con los puntos cardinales del mismo modo que las de El Carnoso II. Por último, los investigadores apuntan la posible presencia de un peribolos, un muro también de doble hilada de mampostería careada (Quesada y Valero 2012,350), tal y como parece verse en El Carnoso II.

Otra necrópolis conquense con estructuras tumulares de gran interés arqueológico es la del Cerro de la Virgen de la Cuesta en Alconchel de la Estrella, donde en 1987 J. M. Millán documentó varias sepulturas comparables a las del Carnoso II por la técnica constructiva, dimensiones y orientación (Millán 1990, 200, fig. 8; 1995, 246-250).

Ya en la provincia de Toledo se localiza la necrópolis ibérica de Palomar de Pintado, donde se han documentado estructuras tumulares en el Fase III de la necrópolis (ss. V-primera mitad del III a.C.). Su excavación ha constatado que además de utilizar piedras, algunas estructuras se construyeron con adobes, material que significativamente también encontramos en El Carnoso II $^{8}$. En Palomar de Pintado aparecen tumbas de planta cuadrada y rectangular, junto con las que presentan superestructuras o túmulos de 2/3 hileras de adobe con un encintado perimetral más claro. Otro tipo de sepultura de tamaño medio, presenta una planta rectangular con estructura internas de adobe que compartimentan el espacio funerario (Carrobles 1995, 251-257). A este tipo de estructuras funerarias se les adjudica paralelos bastante claros en la necrópolis albaceteña de Los Villares de Hoya Gonzalo (Blánquez 1991) y en las conquenses de El Navazo, La Hinojosa (Galán 1980), Buenache de Alarcón (Losada 1966) y Barrionuevo, Iniesta (Valero 1999).

Al SO de El Carnoso, concretamente en el área albaceteña, es donde encontramos el mayor número de necrópolis de cubierta tumular y muy probablemente la conexión cultural de los conjuntos funerarios conquenses y valencianos. Según J. Pereira, A. Taboda y J. Carrobles, habría un vector de iberización desde el SE peninsular hacia el Valle Medio del Tajo (Pereira et al. 2003, 154 y 159) y según nuestra propia observación, esta misma corriente cultural vinculada con el ritual funerario se bifurcaría hacia el valle medio del Turia, llegando a las comarcas montañosas valencianas del Rincón de Ademuz y la Serranía.

Otra necrópolis que cabe citar en esta comparativa es El Tesorico de Agramón-Hellín, y más concretamente las sepulturas 4 y 7 , excavadas por $\mathrm{S}$. Broncano, A. Negrete y A. Martí (1981, 161-162, láms. I y II). En el momento de la intervención la necrópolis había sido expoliada casi completamente (a excepción de la T. 7). Destaca la gran semejanza de los encachados tumulares de El Tesorico con los de El Carnoso II.

Pero sin duda una de las necrópolis de referencia más importante de la zona manchega o albaceteña es la de Los Villares de Hoya Gonzalo (Blánquez 1990) localizada a $114 \mathrm{~km}$ al SO de El Carnoso II. Las excavaciones llevadas a cabo han documentado un total de 40 tumbas de cubierta tumular a las que hay que añadir 106 cremaciones más depositadas en hoyo simple. Se caracteriza la necrópolis por tener varias fases consecutivas. Durante la Fase I son exclusivas las cremaciones en hoyo del "Tipo Solivella" (Oliver 2014); la Fase II es la de máximo auge, es el momento de las sepulturas de cubierta tumular y también de cremación en hoyo. Esta evolución intuimos que pudo ser la del Carnoso II, es decir, una primera necrópolis de cremaciones en hoyo a la que se le superpone una segunda fase en la que se construyen las estructuras tumulares ${ }^{9}$. La Fase III hasta el momento carece de estructuras tumulares. Las tumbas de este último momento, también de cremación en hoyo, se excavan encima de los túmulos de la fase anterior y conservan perfectamente las cubiertas en adobes y tapial.

Los túmulos están realizados con piedras y destaca un mayor cuidado en las hiladas que definen el contorno y el mayor tamaño en los escalones inferiores y los bloques de las esquinas (Blánquez 1990). Este aspecto técnico es similar al verificado en las dos estructuras tumulares de El Carnoso II. Otra coincidencia destacable es la orientación de los túmulos albaceteños y andillanos.

\section{LAS CREMACIONES EN HOYO Y LOS MATE- RIALES ASOCIADOS}

Las cremaciones en hoyo son el tipo de enterramiento más habitual en las necrópolis ibéricas y en el área septentrional de la cultura ibérica peninsular son un tipo prácticamente exclusivo (Cataluña y $\mathrm{N}$ de la Comunidad 


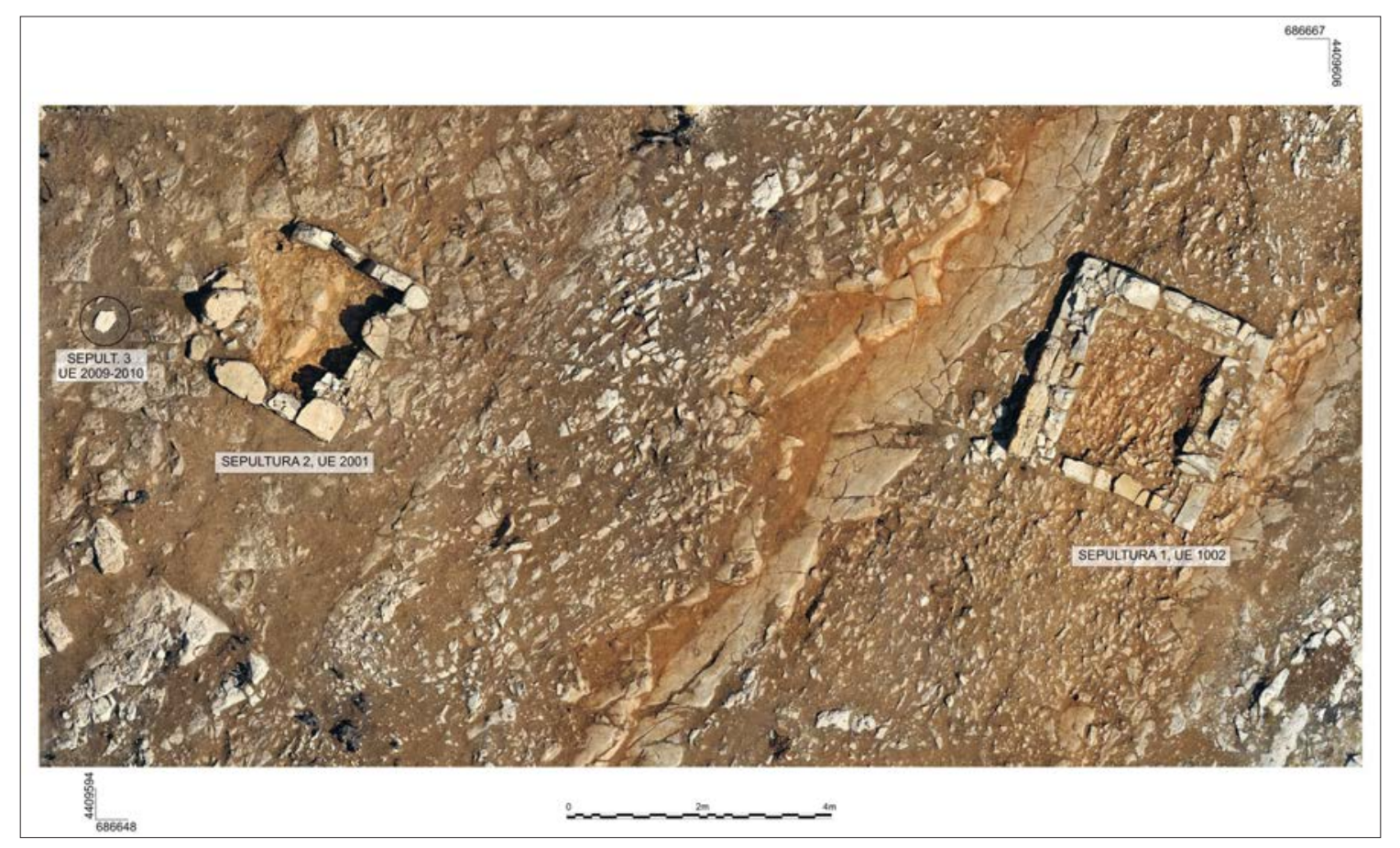

Fig. 24: Ortofoto de la planta general de la necrópolis tras la excavación del año 2014.

Valenciana). Otra característica que define estas necrópolis es la ausencia de escultura animalística y estructuras constructivas de carácter funerario, los empedrados tumulares. Recientemente Artur Oliver define estas necrópolis como "Tipo Solivella" (Oliver 2014). En el territorio valenciano y catalán se conocen desde antiguo numerosas necrópolis de cremación en hoyo que aportan datos materiales de gran interés, son especialmente destacadas las numerosas urnas de orejetas perforadas adheridas a las asas geminadas comparables a las halladas en El Carnoso II.

Estas necrópolis cubren un arco cronológico muy amplio que va de la segunda mitad del s. VI a.C. al s. I a.C. Con el objeto de no ser excesivamente prolijo en este punto comparativo sólo citaremos algunas de las mejor conocidas.

La necrópolis de La Solivella se localiza $100 \mathrm{~km}$ al $\mathrm{N}$ de El Carnoso II, en el término municipal de Alcalà de Xivert (Castelló). En ella se excavaron 28 sepulturas cuya cronología va de final del s. VI a.C. al s. V a.C. (Fletcher 1965; Oliver 2014). En ella encontramos similitudes en cuanto a los materiales cerámicos (urnas de orejetas) y la forma de tapar algunas de ellas:
Las urnas se sujetaban al suelo mediante cuñas de piedra; algunas conservaban la tapadera, bien de orejetas, bien de plato y, en escaso número, de losetas discoidales, idénticas a la pieza 2003-10 (fig. 13). También vemos similitudes en cuanto a los materiales de bronce, pulseras abiertas de sección cuadrada. Otra necrópolis, al parecer expoliada y de la que se ha publicado sólo materiales, es la necrópolis ibérica de La Punta d'Orleyl, Vall d’Uixò (Castelló) (Lázaro et al. 1981). Ésta se localiza a $50 \mathrm{~km}$ al $\mathrm{N}$ de El Carnoso II y es de cronología antigua-plena, ss. VI-III a.C. En su publicación encontramos un referente muy interesante en la fig. 10, 24, un broche de cinturón calado de bronce que iría sujeto a la correa con tres clavos de cabeza hemisférica y punta de sección cuadrada doblada intencionadamente, idéntico a la pieza 1009-10 de El Carnoso II (fig. 20). Asimismo se publican fragmentos de urnas de orejetas (pág. 14, fig. 3, no 4), similares a las de Carnoso II (fig. 20, 10091 y fig. 22, 1013-1). En la necrópolis de Mas Nou de Bernabé, Tírig (Castelló), localizada 103 km al N de El Carnoso también vemos urnas comparables, es decir, urnas con asas geminadas rematadas con las orejetas perforadas (Oliver 2005, 48-50). 


\section{RITUAL FUNERARIO Y SIGNIFICADO SOCIAL DE LAS SEPULTURAS TUMULARES}

En cuanto al ritual funerario observado, todos los datos apuntan a que se practicó la deposición secundaria. Esto significa que se procedió a la cremación del cadáver en un ustrinum próximo a la sepultura y que una vez cremado se recogió de forma selectiva los restos óseos humanos y los objetos personales que el cadáver llevaba en el momento de la cremación. Estos restos podían depositarse en una urna u osario cerámico, o dentro de un recipiente de material perecedero, restos que se colocaron a continuación en el interior de las sepulturas construidas o directamente en simples hoyos excavados en la tierra.

En el Carnoso II se sabe que durante el transcurso o tras el ritual de cremación, hubo otros actos ceremoniales de los que poco se puede decir y cuyas evidencias materiales son muy escasas pero concluyentes y que apuntan al uso-consumo de fauna doméstica en un posible banquete funerario. Uno de los restos faunísticos hallados dentro de la cremación en hoyo de la Sepultura 3 (UE 2009) se corresponde a un metatarso proximal izquierdo de oveja (Ovis aries). En él se observan huellas de descarnado, lo que podría interpretarse como la preparación para su ingesta. También se ha recuperado en la UE 1011, es decir, en un nivel alterado y removido de antiguo, disociado de las sepulturas documentadas, un molar tercero inferior derecho incompleto de un bovino (Bos taurus) de un individuo adulto.

Otros actos ceremoniales practicados pudieron ser las ofrendas y las libaciones rituales. Para estas otras ceremonias los materiales cerámicos son los únicos indicios que se tiene por ahora. La presencia de alguna ánfora, la cerámica común o de cocina, los vasos caliciformes y los platos y morteros podrían apuntar en esta dirección. Como vemos en El Carnoso II, en otras necrópolis ibéricas se asocian algunas formas cerámicas a los rituales funerarios, un ejemplo sería el caso de las ánforas en la necrópolis alicantina de Cabezo Lucero, donde Carmen Aranegui $(1992,177)$ habla de la utilización del vino en estos rituales.

Para el profesor J. J. Blánquez, las necrópolis del sureste meseteño y por extensión las necrópolis tumulares del SE ibérico, área en la que según nuestro criterio se podría incluir la necrópolis de El Carnoso II, reflejan una sociedad aristocrática (no estatal), de jefatura compleja que utiliza los elementos reseñados (las tumbas principescas y ajuares de prestigio) como signos evidenciadores de su propia dignidad, a la vez que justificadora de su situación privilegiada. Dicho de otra forma, las sepulturas tumulares,"principescas"o simples, son la manifestación simbólica y material de la clase aristocrática del momento, s. V a.C. Significativamente en el siglo siguiente, s. IV a.C., se producen cambios en el seno de la sociedad ibérica que se reflejan en las necrópolis que perduran en el ibérico pleno, es el momento en que se abandonan las grandes tumbas tumulares y se estandarizan las sepulturas construidas y de cremación en hoyo. Estos cambios no se pueden observar en el sector excavado de El Carnoso II ya que los indicios que aportó la intervención arqueológica parecen apuntar a que pudo ser abandonada a finales del s. V a.C. o principios del s. IV a.C., cuando el poblado de El Carnoso I todavía sigue habitado. Dichos cambios reflejarían la crisis del modelo aristocrático de la sociedad ibérica, y el surgimiento de estructuras sociales más simples y menos jerarquizadas (Blánquez 1992, 261). La presencia de diferentes tipos de enterramientos en la necrópolis de El Carnoso II, en principio del mismo período cronológico, claramente diferenciados en cuanto al tiempo y trabajo empleado en ellos, corrobora esta estructura jerárquica de la sociedad. Por otro lado, el hecho de que la necrópolis andillana aparentemente sólo tenga un momento de uso, Ibérico Antiguo-inicios del Pleno, cuando sabemos que El Carnoso I perdura hasta la fase final de la cultura ibérica (ss. III-I a.C.), podría estar confirmando lo dicho anteriormente, pero con cambios más drásticos, llegando a ser abandonada la antigua necrópolis y trasladando el cementerio a un lugar por ahora indeterminado.

\section{MATERIAL FAUNÍSTICO (Maria Pilar Iborra Eres ${ }^{10}$ )}

Se han analizado las tres muestras que se recuperaron procedentes de diferentes unidades estratigráficas; UE 1009, UE 1011 y UE 2009. Todos los restos presentan un estado de conservación deficiente, con las corticales muy afectadas por procesos postdeposicionales (ácidos húmicos y raíces). A continuación se describe el contenido de cada una de ellas.

UE 1009

En esta unidad estratigráfica se recuperaron tres restos: dos fragmentos de diáfisis y un fragmento de epífisis de meso mamífero indeterminado. Todos tienen una longitud máxima de entre 1 y $2 \mathrm{~cm}$, y un peso total de $0,33 \mathrm{~g}$. 


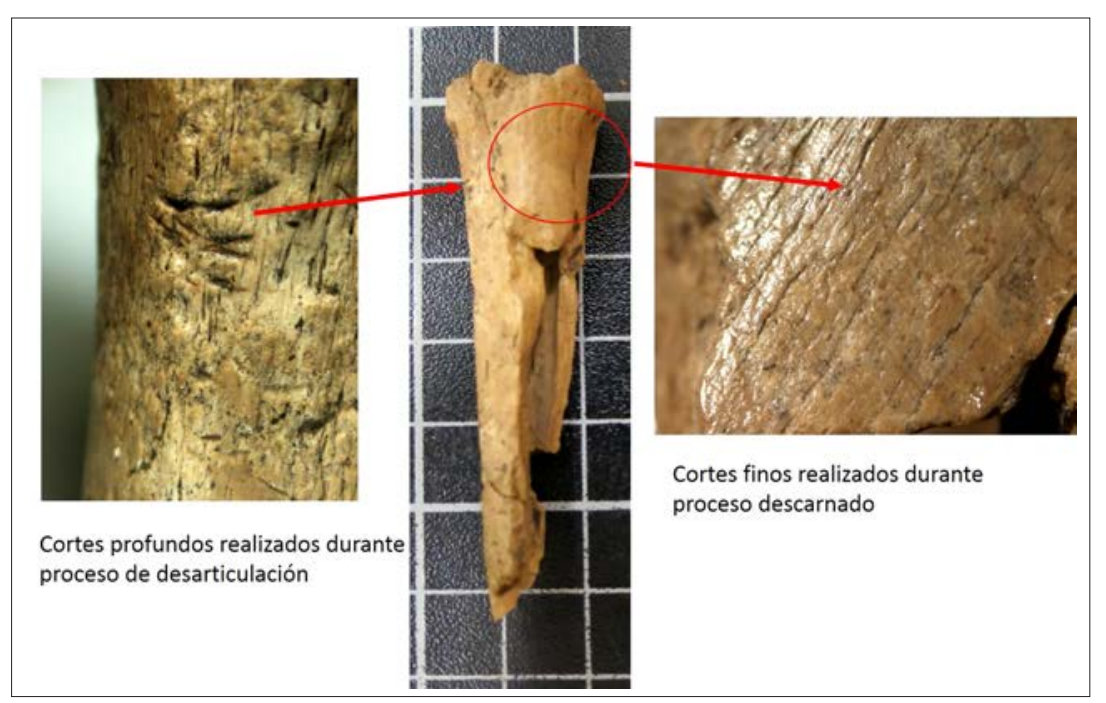

Fig. 25: Material faunístico de la UE 1009 .

\section{UE 1011}

Se ha identificado un molar tercero inferior derecho incompleto de un bovino (Bos taurus). Por el desgaste que se observa en los lóbulos posterior y medial, así como por la altura conservada del metacónido se puede establecer que pertenece a un animal adulto. El peso del resto es de 7,01 g.

\section{UE 2009}

En esta unidad se han identificado un total de siete fragmentos de un mismo elemento, un metatarso proximal izquierdo de oveja (Ovis aries). El peso total es de $5,46 \mathrm{~g}$. Este hueso presenta marcas de desarticulación y descarnado sobre la superficie lateral.

\section{ESTUDIO ANTROPOLÓGICO}

\section{MATERIAL Y MÉTODOS}

Se ha considerado que siguiendo los criterios de $\mathrm{H}$. Duday (1987; idem, 1988 y 1992), el peso de los restos óseos cremados ofrecen un parámetro mucho más fiable que el recuento de los fragmentos, al estar menos ligado al grado de fragmentación. Asimismo, se ha decidido no enumerar la lista detallada de los fragmentos de cada incineración, pasando directamente a describir, en primer lugar, el color de los restos antropológicos para determinar la temperatura aproximada que ejerció la acción del fuego sobre el tejido óseo relacionándolo con la calidad de la combustión. Del mismo modo, los datos morfométricos más relevantes servirán para tratar de establecer la edad y el diagnóstico sexual del individuo, de acuerdo con las indicaciones de Gejvall (1969). Los restos se han clasificado en amplios grupos de edad: inmaduros (0-19 años), adultos (20-39 años), maduros (40-60 años) y seniles (+ de 60 años). También se han examinado las posibles patologías que han sido observadas.

Las cremaciones han pasado por un proceso de cribado en seco para evitar una excesiva fragmentación. A continuación, el sedimento se tamizó utilizando una malla de $1 \mathrm{~mm}$ para recuperar las esquirlas de hueso. Posteriormente, se separaron los fragmentos óseos humanos, tierra, pequeños caracoles y otros elementos como esquirlas cerámicas y algunos carbones. Las porciones de huesos humanos se han medido para determinar si hubo trituración posterior a la cremación. Una vez separados los restos humanos se pesaron por partes anatómicas, los fragmentos pertenecientes al cráneo, huesos largos y el resto del esqueleto post-craneal. Las cremaciones que han llegado hasta nosotros proceden de sepulturas expoliadas con lo cual se ha perdido un número bastante elevado de restos óseos humanos, pero de todos modos se han podido sacar a través del estudio antropológico conclusiones interesantes.

Para la determinación de la edad, nos hemos servido de los fragmentos más importantes para este fin como son: los fragmentos de la bóveda craneal (grado 
de sinóstosis de las suturas) dientes y alvéolos. También del espesor de los huesos del cráneo, tamaño y diámetro de los huesos largos, así como el estado de unión de las epífisis, índice medular y diámetro y longitud de los huesos de las manos y pies. El aspecto de la cavidad cotiloidea, aspecto y tamaño de los cóndilos mandibulares, espesor de la mandíbula y la altura de su sínfisis. La presencia de signos degenerativos en las articulaciones nos ha servido también como guía para los clasificar los sujetos maduros o seniles.

Para la determinación del sexo los fragmentos más interesantes observados son: los del hueso occipital (protuberancia occipital externa e interna), espesor y gracilidad de los huesos, bordes orbitarios superiores, mandíbula y cabezas humerales y femorales. Asimismo, el tamaño de la porción petrosa del temporal, tamaño de los cuerpos vertebrales, tamaño de la cavidad cotiloidea, forma y tamaño de la superficie auricular del coxal, morfología de la escotadura ciática mayor y tamaño de la apófisis mastoides. Los criterios métricos para establecer el sexo de los individuos de Gejvall (1969) solamente los hemos podido aplicar en una incineración, debido al tamaño pequeño y mala conservación de los fragmentos óseos.

\section{ANÁLISIS Y ESTUDIO DE LAS CREMACIONES}

\section{SEPULTURA 1}

El relleno UE 1003 se ha documentado a escasos centímetros al exterior de la Estructura Tumular 1 (UE 1002, o Sepultura 1).

- Coloración: la mayoría de los fragmentos de huesos presentan una coloración blanquecina lo que indica una buena combustión de la incineración y una temperatura mayor de $650{ }^{\circ} \mathrm{C}$.

- El tamaño medio de los fragmentos craneales oscila entre 1-2 cm. El grosor que se ha observado en algunos fragmentos de parietal confirmaría que se trata de un individuo adulto.

- El tamaño medio de los fragmentos de huesos largos está entre los 1 y $2,7 \mathrm{~cm}$. El espesor de la cortical es gruesa en algunos fragmentos del fémur, lo que indicaría un sujeto adulto.

- El tamaño medio de los fragmentos del resto de huesos está entre 0,5-1 cm.

- Conclusiones: los restos óseos calcinados pertenecen a un sujeto adulto de sexo indeterminable. No se han advertido patologías.

\begin{tabular}{|l|c|}
\hline Peso total & $130 \mathrm{~g}$ \\
\hline Huesos humanos & $120 \mathrm{~g}$ \\
\hline Tierra y polvo de hueso & $3 \mathrm{~g}$ \\
\hline Fragmentos cerámicos & $0 \mathrm{~g}$ \\
\hline Malacofauna & $2 \mathrm{~g}$ \\
\hline Piedras & $4,5 \mathrm{~g}$ \\
\hline Carbones & $0,5 \mathrm{~g}$ \\
\hline Fauna & $0 \mathrm{~g}$ \\
\hline Metal & $0 \mathrm{~g}$ \\
\hline
\end{tabular}

Peso por partes anatómicas

\begin{tabular}{|l|c|}
\hline Cráneo & $25 \mathrm{~g}$ \\
\hline Huesos largos & $55 \mathrm{~g}$ \\
\hline Otros & $40 \mathrm{~g}$ \\
\hline
\end{tabular}

Fig. 26. Contenido de la UE 1003.

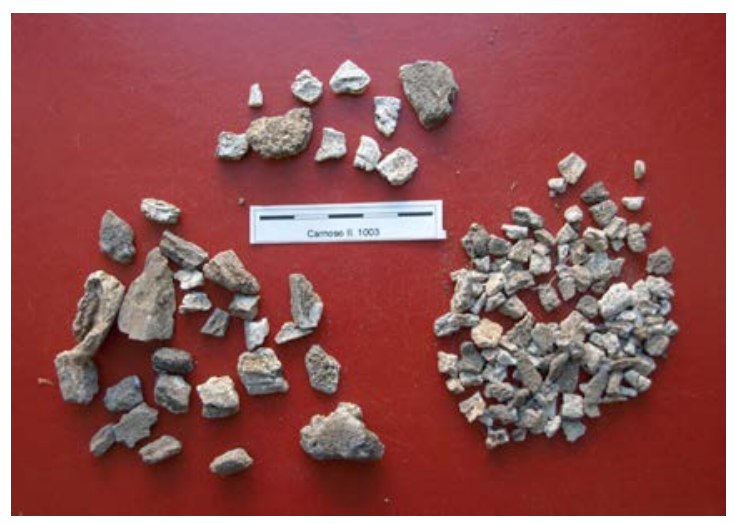

Fig. 27: Restos antropológicos de la UE 1003, asociados a la Sepultura 1 (UE 1002).

\section{SEPULTURA 2}

Como en el caso anterior, el relleno UE 2008, donde aparecieron la mayor parte de los restos antropológicos, se ha documentado al exterior de la Estructura Tumular 2 (UE 2001), concretamente a 1,5 m del lado noroeste y se asocian a la Sepultura 2. Los rellenos UUEE 2002 y 2003 corresponden al interior de dicha estructura.

- Coloración: la mayoría de los fragmentos de huesos muestran una coloración blanquecina lo que indica una buena combustión de la incineración y una temperatura mayor de $650{ }^{\circ} \mathrm{C}$.

- El tamaño medio de los fragmentos craneales oscila entre $1-3 \mathrm{~cm}$. Las suturas craneales están cerradas 
pero no obliteradas lo que nos indica un sujeto adulto. El grosor que se ha observado en algunos fragmentos de parietal confirmaría que se trata de un individuo adulto. El espesor en 1a cortical, siguiendo a Gejvall, 1969 (máximo espesor del díploe en la zona parietal) da como resultado $1 \mathrm{~cm}$. El resultado nos remite a un sujeto masculino. También se ha recuperado un fragmento de incisivo que no ha aportado más información.

- El tamaño medio de los fragmentos de huesos largos está entre los 1,5 y $3 \mathrm{~cm}$. El espesor de la cortical es muy gruesa lo que indicaría un sujeto adulto robusto.

\begin{tabular}{|c|c|}
\hline la (calota craneal) & $1 \mathrm{~cm} \hat{\delta}$ \\
\hline Peso total & $440 \mathrm{~g}$ \\
\hline Huesos humanos & $425 \mathrm{~g}$ \\
\hline Tierra y polvo de hueso & $5 \mathrm{~g}$ \\
\hline Fragmentos cerámicos & $2 g$ \\
\hline Malacofauna & $0 \mathrm{~g}$ \\
\hline Piedras & $8 \mathrm{~g}$ \\
\hline Carbones & $0 \mathrm{~g}$ \\
\hline Fauna & $0 \mathrm{~g}$ \\
\hline Metal & $0 \mathrm{~g}$ \\
\hline \multicolumn{2}{|l|}{ Peso por partes anatómicas } \\
\hline Cráneo & $90 \mathrm{~g}$ \\
\hline Huesos largos & $215 \mathrm{~g}$ \\
\hline Otros & $120 \mathrm{~g}$ \\
\hline
\end{tabular}

Fig. 28. Contenido de las UUEE 2008-2002-2003.

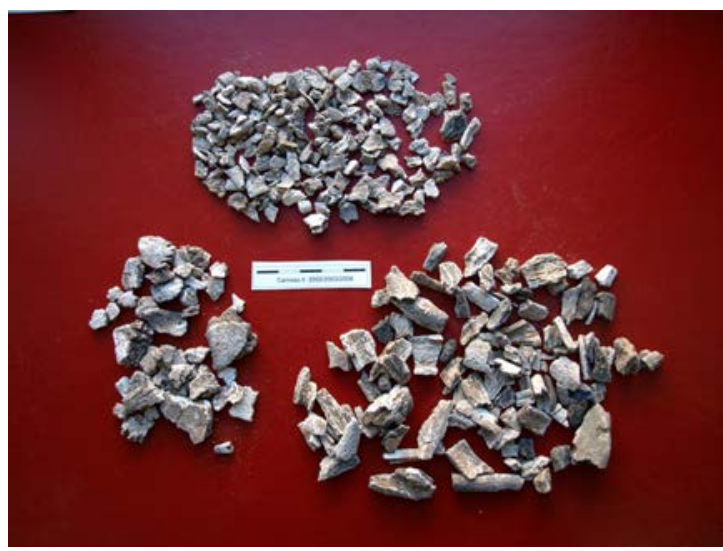

Fig. 29: Restos antropológicos de las UUEE 2008-2002-2003, asociados a la Sepultura 2 (UE 2001).
- El tamaño medio de los fragmentos del resto de huesos está entre 1-1,6 cm

- Conclusiones: los restos óseos calcinados pertenecen a un sujeto masculino adulto. No se han advertido patologías.

\section{SEPULTURA 3}

La UE 2009 corresponde al relleno de la Sepultura 3, UE 2010 o Loculus 1. En éste se recuperó íntegro el depósito de la cremación.

- Coloración: aunque hay algunos fragmentos de color blanco el color predominante de la incineración es el

\begin{tabular}{|l|c|}
\hline Peso total & $300 \mathrm{~g}$ \\
\hline Huesos humanos & $295 \mathrm{~g}$ \\
\hline Tierra y polvo de hueso & $0 \mathrm{~g}$ \\
\hline Fragmentos cerámicos & $0 \mathrm{~g}$ \\
\hline Malacofauna & $\mathrm{lg}$ \\
\hline Piedras & $4 \mathrm{~g}$ \\
\hline Carbones & $0 \mathrm{~g}$ \\
\hline Fauna & $0 \mathrm{~g}$ \\
\hline Metal & $0 \mathrm{~g}$ \\
\hline
\end{tabular}

Peso por partes anatómicas

\begin{tabular}{|l|c|}
\hline Cráneo & $60 \mathrm{~g}$ \\
\hline Huesos largos & $95 \mathrm{~g}$ \\
\hline Otros & $140 \mathrm{~g}$ \\
\hline
\end{tabular}

Fig. 30: Contenido de la UE 2009.

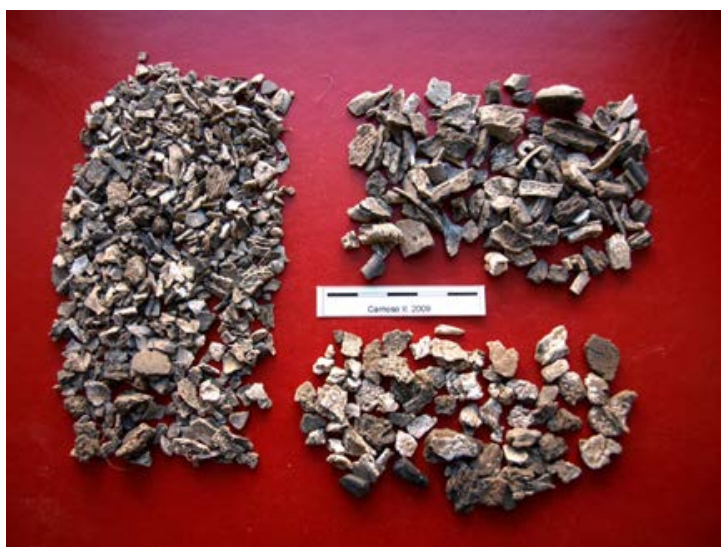

Fig. 31: Restos antropológicos de la UE 2009, Sepultura 3 (UE 2010). 
grisáceo, indicando una combustión regular y una temperatura entre los $550-600{ }^{\circ} \mathrm{C}$.

- El tamaño medio de los fragmentos craneales oscila entre 1-2 cm. Las suturas craneales están cerradas pero no obliteradas lo que nos indica un sujeto adulto. El espesor de los fragmentos del díploe es compatible con la de un sujeto adulto aunque el desgaste dental observado en un canino y en un fragmento de incisivo es propio de sujetos de edad madura.

- El tamaño medio de los fragmentos de huesos largos está entre los 1,5 y $2,3 \mathrm{~cm}$. El espesor de la cortical es bastante grueso lo que indicaría un sujeto adulto.

- El tamaño medio de los fragmentos del resto de huesos es de $1 \mathrm{~cm}$.

- Conclusiones: los restos óseos calcinados pertenecen a un sujeto adulto de edad madura (entre 40-60 años) de sexo indeterminable. No se han advertido patologías.

\section{CONSIDERACIONES GENERALES}

En primer lugar hay que destacar que el tamaño de la muestra es muy pequeño (tres cremaciones) y que las sepulturas han sido expoliadas. Aún así se puede deducir, atendiendo a la coloración que presentaban los restos antropológicos, que las dos cremaciones que se encontraban en el interior de las Sepulturas 1 y 2 (de color blanquecino) muestran una mayor temperatura de combustión que la asociada a la Sepultura 3 o loculus 1 que presentaba una coloración grisácea. Lo que podría traducirse en un tratamiento diferencial entre las cremaciones depositadas en las estructuras tumulares y las depositadas directamente en un hoyo en el suelo, loculus. Este tratamiento diferencial tiene que ver con la cantidad y calidad de combustible de la pira funeraria así como la oxigenación durante el proceso de cremación. Los resultados del estudio antropológico han confirmado que las incineraciones de calidad de cremación intensas coinciden con construcciones funerarias más elaboradas, lo que sugiere un tratamiento diferencial en el proceso de incineración y de deposición de los restos cremados, es decir hay una diferencia de tratamiento respecto a la muerte entre dos clases sociales una con más poder económico y social que puede costearse un entierro y hacer ostentación de su sepultura, acorde a su estatus, y otra de clase social más baja que participa del mismo rito pero con diferencias en cuanto a un peor tratamiento en la pira funeraria y una modesta sepultura. Investigaciones futuras sobre necrópolis ibéricas podrán constatar o desmentir este tratamiento diferencial que se ha observado en el ritual de la muerte en las incineraciones de El Carnoso II. El estudio antropológico ha determinado que los tres individuos cremados son adultos y que en uno de estos monumentos funerarios (Sepultura 2) estuvo enterrado un sujeto masculino adulto de cierta robustez (complexión fuerte). En cuanto a representación del esqueleto atendiendo al peso, la parte más representada en las cremaciones son los huesos largos seguido de otros huesos del esqueleto y por último del cráneo. En cuanto a la diferencia de temperatura de las cremaciones en base a la coloración, dos de ellas sobrepasaban $\operatorname{los} 650{ }^{\circ} \mathrm{C}$ y una de ellas estaba entre $550-600{ }^{\circ} \mathrm{C}$.

\section{ARQUEOASTRONOMíA (Ángel Flores Martínez) ${ }^{11}$}

Las orientaciones de estructuras funerarias suelen hacer referencia a uno de estos tres esquemas: orientación local, referida al entorno, elementos del paisaje, elevaciones con significados rituales u otras. Orientación geográfica, referida a los puntos cardinales, la más habitual es la orientación E-O. El este es el punto cardinal por excelencia, de ahí persiste nuestro concepto de orientación, derivado de oriente. Por último la orientación astronómica, en la cual las líneas principales del elemento siguen una pauta obtenida de las posiciones o movimientos de los astros.

Con el fin de averiguar cual sería el motivo de tal orientación hemos realizado el presente estudio, en el que

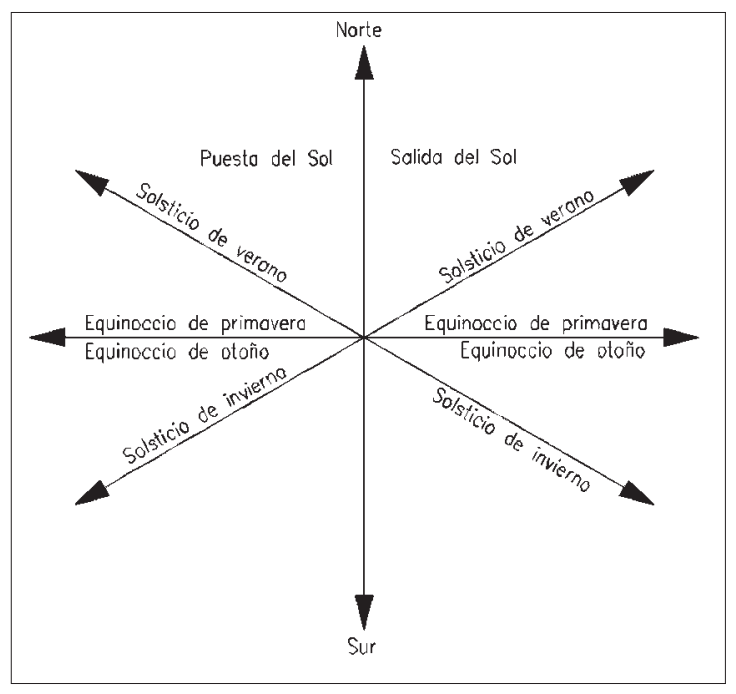

Fig. 32: Orientaciones astronómicas significativas referidas al Sol. 
incluimos la determinación de ésta, el cálculo de los ortos y ocasos solares, el estudio del paisaje circundante, y una hipótesis sobre los motivos que pudieron llevar a sus constructores a utilizar esta orientación y no otra.

Para obtener las orientaciones de los túmulos de El Carnoso II hemos tomado como línea principal la que sigue el lado $\mathrm{S}$ de los mismos. El estado de conservación de la base es aceptable para la medida del acimut del mismo.

\section{MÉTODO Y OBTENCIÓN DE DATOS}

Los datos se han recopilado directamente sobre el yacimiento. Para situar los diferentes elementos se emplean dos ángulos, el acimut y la altura. Acimut es el ángulo horizontal medido desde el $\mathrm{N}$ en el sentido $\mathrm{E}, \mathrm{S}$, O. La altura es el ángulo vertical medido desde el horizonte hasta el punto en cuestión. Para determinar el acimut se ha empleado una brújula electrónica cuya precisión es de $0,5^{\circ}$, suficiente para el propósito de la investigación. Las alturas se han medido con un klinómetro con precisión de $\pm 0,2^{\circ}$. El conjunto klinómetro y brújula está unido a un anteojo con retículo que ha servido para determinar con mayor precisión la orientación de algunos elementos del paisaje. Con el fin de precisar la bondad de las medidas, se han tomado las direcciones a diferentes puntos geográficos fácilmente identificables en la cartografía; posteriormente las coordenadas de estos puntos han sido obtenidas a través de la información Web publicada en el visor CITMA de la Generalitat Valenciana. Las verificaciones efectuadas confirman que los errores en las direcciones obtenidas por la brújula son inferiores a un grado.

La variación de la declinación magnética se ha tomado del programa de cálculo de la misma, que el Instituto Geográfico Nacional pone a disposición de los usuarios a través de su sitio Web. Para las coordenadas y fecha concretas es de $0^{\circ} 23^{\prime} \mathrm{O}$.

\section{RESULTADOS}

Aplicadas las correcciones correspondientes se obtiene que el acimut del lado S de la Sepultura 1 es de $290^{\circ}$ y el lado adyacente $24^{\circ}$. El acimut del mismo lado $\mathrm{S}$ del túmulo 2 o Sepultura 2, es de $291^{\circ}$. La situación de ambos túmulos es tal que la línea que une sus centros es E-O.

La dirección al poblado ibérico El Carnoso I es acimut $=357^{\circ}$.
El acimut del yacimiento El Carnoso III (aun por estudiar) es de $280^{\circ}$ y su elevación $+2,6^{\circ}$

\section{EXPOSICIÓN}

Es significativo que los dos túmulos tienen la misma orientación, con una pequeña diferencia entre ellos, del orden de un grado, lo que nos hace pensar que las orientaciones de ambos no son aleatorias y tenían un valor en si mismas. También es destacable que la línea que une los centros de ambos túmulos está orientada en sentido E-O. Analizado el entorno vemos que la dirección desde los túmulos hacia el poblado El Carnoso I es $357^{\circ}$, prácticamente $\mathrm{N}$, no parece que fuese esa la dirección deseada, ni los laterales ni las diagonales siguen esa dirección, que por otra parte hubiese sido muy sencilla de realizar.

La línea de la parte superior de la loma en la que se encuentran los túmulos, que separa ambas vertientes sigue la dirección E-O, por lo que tampoco parece que se pretendiesen alinear con dicha dirección. Esta hubiese sido la disposición más sencilla, ambos túmulos alineados entre sí, en la parte más alta de la loma, además de ser la orientación geográfica más habitual, E-O, y que como ya se mencionó no es el caso.

La orientación astronómica parece la correcta, sobre esta cuestión cabrían lo siguientes comentarios. La vida en las sociedades a las que nos referimos debía estar en gran armonía con la naturaleza, su vida cotidiana debía estar marcada por el Sol, su salida o puesta debía ser objeto de observación muy frecuente, si no diaria. La regularidad de los ciclos astronómicos no tiene parangón con ningún otro, la sucesión de día y noche, las fases de la Luna, y los puntos de orto y ocaso del sol, son muy evidentes para no darse cuenta de los ciclos que se suceden. La agricultura, precisa conocer los ciclos estacionales, pero también la vida social, por sencilla que fuese necesitaría algún patrón de repetición temporal. Para ejercer el poder sería importante demostrar algún conocimiento especial, por que no sobre los movimientos principales del Sol y la Luna.

Entre los posibles marcadores de tiempo, la determinación de la posición de los ortos y ocasos del sol en los solsticios no es la más complicada, basta con seguirlos para tomar algunas referencias relativas a las direcciones por las que se producen. La forma más simple de determinar los equinoccios, o el punto medio entre solsticios requiere haber determinado primero éstos, de donde se derivan los puntos $\mathrm{E}$ y $\mathrm{O}$. 
Fig. 33: Vista del Puntal de Simón en la que se han señalado las posiciones de los dos túmulos con flechas cortas y la dirección por la que se pone el Sol con una flecha larga.

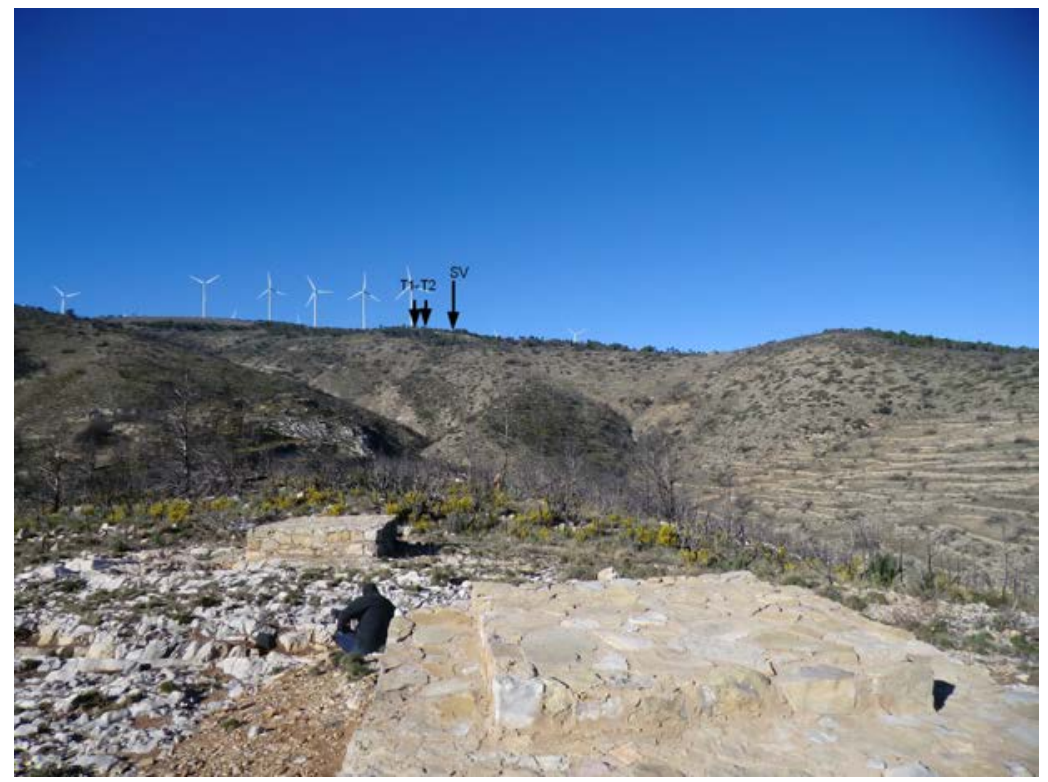

La orientación hacia el orto del solsticio de invierno es habitual en la mayoría de las tumbas de la necrópolis fenopúnica de Baria (Belmonte 1999). El mismo esquema se presenta en la necrópolis arcaica de Útica s. VII a.C. (Belmonte et al. 1998).

Aproximadamente la misma dirección del orto en el solsticio de invierno, en sentido opuesto, indica el ocaso en el solsticio de verano. La posibilidad, que creemos más acertada, sería que la orientación estuviese referida al ocaso solar en el solsticio de verano.

En el yacimiento investigado la puesta de sol se produce por encima del Cerro Simón, una montaña, cuya cima es alargada y ligeramente descendente hacia el norte, la altura es bastante superior a la que se encuentran las estructuras tumulares. Para hallar el punto exacto por el que se pone el sol es necesario confeccionar el perfil de la cima, para ello se han obtenido una serie de puntos utilizando el equipo ya descrito, obteniendo que la altura del sol en el ocaso es de $8,5^{\circ}$.

\section{CÁLCULO ASTRONÓMICO}

Para calcular el acimut del ocaso solar se ha empleado la fórmula derivada de la transformación de coordenadas (Martínez et al. 2001, 76):

$$
A z=\operatorname{arcos}\left(\frac{\operatorname{sen} \delta-\operatorname{senh} \cdot \operatorname{sen} \Phi}{\cosh \cdot \cos \Phi}\right)
$$

Es conveniente precisar que el movimiento que con más amplitud modifica las coordenadas de los astros a lo largo del tiempo es la Precesión de los Equinoccios, y que esta no afecta a las direcciones de salida y puesta del Sol. Tanto el orto y ocaso del sol como el de la Luna, solo se ve afectado por la inclinación de la eclíptica. Esta inclinación varía con el tiempo, su valor es pequeño en un lapso de 2500 años, aun así se ha calculado empleando el método incluido en Curso de Astronomía General (Bakulin et al. 1987, 37) obteniendo que en este plazo se ha reducido en 17,5 minutos de arco.

Con estos datos se ha calculado el acimut del Sol al ponerse por encima del Cerro Simón y se ha obtenido un valor de $293,5^{\circ}$. La posición se ha señalado a la imagen situando el punto por el que se pone el Sol el día del solsticio de verano.

\section{VALORACIÓN}

En el estudio de los túmulos del yacimiento ibérico de El Carnoso II es significativo que las dos sepulturas construidas tienen la misma orientación, con una diferencia entre ellas de un grado, lo que nos invita a creer que la orientación no se hace al azar, y que tiene gran importancia. Cabría afirmar que la orientación forma parte de la construcción.

La orientación de ambas estructuras túmulares no está dirigida, ni en sus diagonales ni en sus laterales, hacia el poblado, ni sigue la orientación de la elevación 
en la que se encuentra. Tampoco sigue la orientación E-O o la del orto en el solsticio de invierno. La orientación se dirige con buena precisión al ocaso en el solsticio de verano, lo que muestra que está fue la orientación elegida. También es significativo que la Sepultura 2 se aproxima más a la dirección del ocaso. Por otra parte parece que hay una clara concordancia entre la idea de la muerte y el ocaso del Sol.

\section{CONSIDERACIONES FINALES}

El carácter ibérico del poblamiento antiguo en la comarca de la Serranía central (ss. VI-I a.C.), ha quedado patente con la publicación de los resultados de la intensa y reciente prospección de dicho territorio (Burriel y Ruiz, 2015) y, más si cabe, con la excavación parcial de la necrópolis ibérica de El Carnoso II de Andilla. Pero lo cierto es que la primera aportación a la cuestión de las manifestaciones de la cultura ibérica en la comarca fueron las excavaciones llevadas a cabo por el Servicio de Investigación Prehistórica de la Diputación de Valencia en los años 1985-1990 y 2008 en la aldea ibérica de La Seña (El Villar del Arzobispo), yacimiento ibérico situado en la periferia $S$ de la Serranía central en el que se observa dos niveles, uno inicial centrado en el Ibérico Antiguo (ss. VI-V a.C.) y otro nivel superpuesto desarrollado durante el Ibérico Pleno (ss. IV-III a.C.) (Bonet y Mata 1997). La Seña, yacimiento que se vincula al territorio socio-político de la antigua Edeta (Tossal de Sant Miquel, Llíria), comarca de Camp de Túria, creemos que pudo jugar un papel de capital importancia en el proceso de iberización de toda la Serranía. Su situación estratégica, de auténtica cabeza de puente entre la costa y el interior, pudo hacer de este lugar una pieza clave del citado proceso a partir de flujos e influencias diversas.

Sin olvidar los importantes datos que aporta el singular yacimiento de La Seña al proceso de iberización comarcal, la información que proporciona la primera intervención arqueológica en El Carnoso II no es menos trascendente, ya que incrementa sustancialmente el conocimiento que hasta ahora teníamos de los iberos en la comarca y nos indica un posible nuevo flujo de influencia cultural de procedencia $\mathrm{S}$ y $\mathrm{O}$. Estas nuevas aportaciones a la arqueología ibérica y más concretamente al mundo funerario, son de gran relevancia arqueológica y reveladoras de una temprana iberización comarcal. También nos permiten "encajar" con total nitidez esta necrópolis en una determinada área geográfica y cultural, el área del SE ibérico, aunque en una zona marginal.

El área albaceteña y murciana, en la que la arqueología del mundo funerario está muy desarrollada, es donde se encuentran los mejores paralelos formales para las tumbas construidas en El Carnoso II. Tras consultar los numerosos trabajos que de forma general o de forma específica tratan el tema de las necrópolis ibéricas valencianas (Blánquez 1990; Martínez 1989; Oliver 1981, 2014; Gil-Mascarell 1973; Abad y Sala 1992; Aldana 1986; Mata 1993; Izquierdo 2000; Aparicio 1991, etc.), se constata que la inmensa mayoría de las conocidas son del Tipo I de Blánquez, es decir, de cremación en hoyo. Las referencias a las necrópolis de cubierta tumular en el territorio valenciano son escasas y como era de esperar no ha sido fácil encontrar reflexiones sobre este tipo de necrópolis, salvo la excepción, ya citada, de El Corral de Saus (Moixent) que se vincula con la vía Heraclea, el corredor natural de Almansa (Albacete) y con las necrópolis manchegas y murcianas (Abad y Sala 1992).

\begin{tabular}{|l|c|c|c|}
\hline \multicolumn{1}{|c|}{ Conjunto de materiales } & Cronología & Frags./P.C. & \% total \\
\hline Cerámica ibérica de clase A & Ibérica (ss. V-IV a.C.) & 1163 & 74,08 \\
\hline Cerámica ibérica de clase B & Ibérica (ss. V-IV a.C.) & 182 & 11,59 \\
\hline Cerámica ibérica gris & Ibérica (ss. V-IV a.C.) & 21 & 1,34 \\
\hline Cerámica a mano & B.F.-H.A./Ibérica & 97 & 6,18 \\
\hline Material de construcción (adobe) & Ibérica (ss. V-IV a.C.) & 1 & 0,06 \\
\hline Bronce/plata & Ibérica (ss. V-IV a.C.) & 90 (p.d.) & 5,73 \\
\hline Hierro & Ibérica (ss. V-IV a.C.) & 8 & 0,51 \\
\hline Piedra & Ibérica (ss. V-IV a.C.) & 1 & 0,06 \\
\hline Fauna & Ibérica (ss. V-IV a.C.) & 2 & 0,13 \\
\hline Malacofauna & Moderna, s. XVI (¿?) & $\mathbf{1}$ & 0,06 \\
\hline Cremaciones & Ibérica (s. V a.C.) & $3(840$ gr) & 0,19 \\
\hline Numismática & Moderna, s. XVI & $\mathbf{I}$ & 0,06 \\
\hline TOTAL & & $\mathbf{1 5 7 0}$ & $\mathbf{1 0 0}$ \\
\hline
\end{tabular}


Otro aspecto del que cabe hablar es el relacionado con la cultura material exhumada que significativamente encuentra similitudes en todas las áreas geográficas ibéricas, pero especialmente con el área costera, desde la desembocadura del Ebro a la desembocadura del Segura.

Asímismo, se ha querido analizar el significado social y político que se desprende de los diferentes tipos de sepulturas documentadas, de los datos estratigráficos-topográficos y otros aspectos materiales. Pero desgraciadamente la tarea de analizar el conjunto de la cultura material (fig. 34) resulta harto difícil, casi imposible, al haber sido saqueadas las tumbas y desprovistas de los ajuares que en ellas se depositaron, y que casi sin duda eran el reflejo del estamento social al que pertenecieron los individuos allí enterrados.

A pesar de los problemas detectados y la escasa superficie excavada, apenas $200 \mathrm{~m}^{2}$ de los más de $2000 \mathrm{~m}^{2}$ que calculamos que tendría el cementerio, El Carnoso II aporta una gran novedad a la arqueología funeraria ibérica peninsular, se convierte a partir de ahora en una nueva necrópolis del área del SE ibérico (vértice septentrional) que se suma a las que en su día recogieran J. J. Blánquez y J. Aparicio para la Comunidad Valenciana: Corral de Saus, La Albufereta (Rubio 1986), El Molar (Blánquez 1990) y Los Corrales de la Nava (Aparicio 1991).

El hecho de estar aparentemente expoliada no la desmerece en absoluto ya que su gran extensión y la presencia de otras estructuras tumulares así como un posible peribolos, compensan esta desafortunada realidad y estamos convencidos de que se hallarán nuevas cremaciones en hoyo.

Por último, la excavación, consolidación y musealización parcial de la necrópolis ibérica de El Carnoso II contribuye a una nueva línea de investigación arqueológica vinculada al mundo religioso y espiritual de los iberos en la Serranía y Comunidad Valenciana.

\section{NOTAS}

1. La excavación arqueológica y posterior consolidación fueron sufragadas por la Dirección General de Patrimonio Cultural de la Conselleria de Educación, Investigación, Cultura y Deporte de la Generalitat Valenciana y el Ayuntamiento de Andilla y la consolidación arquitectónica fue dirigida por el arquitecto municipal de Andilla Javier Hidalgo Mora.

2. Información extraída de: Rodrigo, C. (1999): Geografía de Andilla. Ayto. de Andilla.

3. La prospección selectiva de los más de 120 yacimientos de la comarca ha permitido localizar dos nuevas necrópolis de cremación: Castillo del Collado II (Alpuente) y Hoya de Antaño II (Calles), ambas expoliadas.
4. Agradecemos la colaboración desinteresada del numismático Tomás Hurtado en la identificación y catalogación de la única moneda aparecida durante los trabajos de excavación.

5. Queremos manifestar nuestro más sincero agradecimiento a la profesora Consuelo Mata Parreño por su amabilidad y sus consejos a la hora de redactar el presente artículo.

6. A estos seis individuos se ha de sumar otros dos de la UE 2003, lo que hace un número total de ocho urnas de orejetas.

7. Nos referimos a los que han sido publicados, por lo tanto excluimos de esta comparativa la necrópolis ibérica de Hoya de Antaño III (Calles).

8. El inventario de materiales ha proporcionado una pella o fragmento de adobe de lo que deducimos que se utilizó este material en algún momento de la construcción de las sepulturas.

9. Esta hipótesis de trabajo sólo se podrá corroborar o descartar a medida que se vaya conociendo mejor la necrópolis andillana.

10. El estudio y catalogación de la escasa fauna recuperada ha sido efectuado por la zooarqueóloga Pilar Iborra, a la que agradecemos enormemente su colaboración desinteresada.

11. Queremos dejar constancia de nuestro agradecimiento más sincero a nuestro buen amigo y astrónomo Ángel Flores por su aportación en este artículo a la arqueoastronomia de la necrópolis de El Carnoso II de Andilla.

\section{BIBLIOGRAFÍA}

ABAD, L.; SALA F. (1992): Las necrópolis ibéricas del área de Levante, Actas del Congreso de Arqueología Ibérica, Las necrópolis, Madrid. 145-167.

ALDANA, C. (1986): Necrópolis ibéricas valencianas. Ensayo de clasificación tipológico-cronológica, Archivo de Arte Valenciano 67, 109-115.

APARICIO, J. (1990-1991): La Nava (Castielfabib. Rincón de Ademuz. Valencia): necrópolis y poblado ibérico, Verdolay 2 , 179-184.

ARANEGUI, C. (1992): La necrópolis de Cabezo Lucero (Guardamar del Segura, Alicante), Congreso de Arqueología Ibérica. Las Necrópolis. Serie Varia 1, Universidad Autónoma de Madrid, 169-188.

ARANEGUI, C; JODIN, A.; LLOBREGAT, E. A.; ROUILLARD, P.; UROZ, J. (1982): Fouilles du site ibérique de Cabezo Lucero (Guardamar del Segura, Alicante) Troisième campagne, Mélanges de la Casa de Velázquez XIX/1, Madrid, 427-436.

BAKULIN, P. I.; KONONOVICH, E. V.; MOROZ, V. I. (1987): Curso de Astronomía General, Moscova.

BELMONTE, J. A. (1999): Las leyes del cielo: Astronomía y civilizaciones antiguas, Madrid.

BELMONTE, J. A.; ESTEBAN, C.; JIMÉNEZ, J. J. (1998): Mediterranean archaeoastronomy and archaeotopography: pre-Roman tombs of Africa Proconsularis, Journal for the History of Astronomy, Archaeoastronomy Supplement, Vol. 29, 87.

BLÁNQUEZ, J. J. (1984): Las necrópolis ibéricas de la Provincia de Albacete, Congreso de Historia de Albacete, vol. I, Albacete, 185-209. 
BLÁNQUEZ, J. J. (1990): La formación del mundo ibérico en el Sureste de la Meseta, Albacete.

BLÁNQUEZ, J. J. (1992): Las necrópolis ibéricas en el Sureste de la Meseta, Congreso de Arqueología Ibérica. Las Necrópolis. Serie Varia 1, Madrid, 235-278.

BLÁNQUEZ, J. J. (1993): El mundo funerario albacetense y el problema de la escultura ibérica: la necrópolis de los Villares, Arqueología en Albacete, Madrid, 111-128.

BLÁNQUEZ, J. J. (1995): La necrópolis ibérica de El Salobral (Albacete), El Mundo ibérico: una nueva imagen en los albores del año 2.000, Junta de Comunidades de Castilla la Mancha, Toledo, 258-266.

BONET, H.; MATA, C. (1997): La cerámica ibérica del siglo V a.C. en la Edetania, Recerques del Museu d'Alcoi 6, 31-47.

BURRIEL, J. M.; MATA, C. (2013): L'oppidum ibèric d'El Tòs Pelat (L'Horta Nord, València), Monte Catano 14, Revista del Museu Municipal "Les Maleses”, Montcada i Reixac, 75-97.

BURRIEL, J. M.; RUIZ, J. J. (2015): El poblamiento ibérico en la comarca de la Serranía (Valencia), s. VI-I a.C. Aproximación al modelo de ocupación del territorio, SagvntvmPLAV 47, 29-50. DOI: https://doi.org/10.7203/SAGVNTVM.47.5029

BRONCANO, S.; NEGRETE, A.; MARTÍN, A. (1981): Avance de las excavaciones de urgencia realizadas en "El Tesorico", Agramón-Hellín, Al-Basit 10, 159-180.

CARROBLES, J. (1995): La necrópolis ibérica de Palomar de Pintado, El mundo ibérico: una nueva imagen en los albores del año 2.000, Junta de Comunidades de Castilla la Mancha, Toledo, 251-258.

CHAPA, T.; PEREIRA, J. (1992): La necrópolis de Castellones de Céal (Hinojares, Jaén), Congreso de Arqueología Ibérica. Las Necrópolis. Serie Varia 1, Madrid, 431-454.

CUADRADO, E. (1987): La necrópolis ibérica de El Cigarralejo (Mula, Murcia), Bibliotheca Praehistorica Hispana XXIII, Madrid.

DUDAY, H. (1992): Etude des ossements humains, Le tumulus de Lery Souillac (Lot) (Giraud J. P.), Archives d'Écologie Préhistorique 12, 43-54.

DUDAY, H. (1988): Le tumulus-Cromlech de Millagate IV. Etude des restes humains, Munibe 40, 105-110.

DUDAY, H., (1987): La quantification des restes humains. Application à l'étude des sépultures à incinération, ou des différentiels autres que la conservation, Actes de la table-ronde de la R.C.P. $742 d u$ CNRS, Saint Germain-en-Laye, Mai, 1987.

ESTEBAN, C. (2002): Elementos astronómicos en el mundo religioso y funerario ibérico, TP 59 (2), Madrid, 81-100.

FLETCHER, D. (1965): La necrópolis de la Solivella (Alcalà de Chivert), Serie Trabajos Varios. S.I.P. 32, Valencia.

GALÁN, C. (1980): Memoria de la primera campaña de excavación en la necrópolis del Navazo (La Hinojosa, Cuenca) 1976 , NAH X, 141-207.

GARCÍA, C. (1990): Notas sobre la necrópolis ibérica de Los Nietos, Verdolay, Homenaje a E. Cuadrado 2, Murcia, 161-171.
GARCÍA-GELABERT, M. P.; BLÁZQUEZ, J. M. (1992): Las necrópolis oretanas de Cástulo. Paralelos con las necrópolis ibéricas del Sureste, Congreso de Arqueología Ibérica. Las Necrópolis. Serie Varia 1, 455-472.

GEJVALL, N.G. (1969): Cremations, Science in Archeology (Brothwell, D. y Higgs, E., eds.), New York, 468-479.

GEJVALL, N.G. (1980): Cremaciones, Ciencia en Arqueología (Brothwell, D. y Higgs, E., comp.), Madrid, 482-493.

GENERA, M.; BARRIL, M.; PERIRET, J. (2008): Datos para una definición de la necropolis de Mianes, Santa Bàrbara-Tortosa (Montsià-Baix Ebre, Tarragona), Zephyrus 62, 207-229.

GIL-MASCARELL, M. (1973): Restos funerarios ibéricos en las provincias de Castellón y Valencia, Papeles del Laboratorio de Arqueología 9, 29-47.

IZQUIERDO, I. (2000): Monumentos funerarios ibéricos: los pilares-estela, Serie de Trabajos Varios. S.I.P. 98. Valencia.

LAZARO, A.; MESADO, N.; ARANEGUI, C.; FLETCHER, D. (1981): Materiales de la Necrópolis Ibérica de Orleyl (Vall d'Uxó, Castellón), Serie Trabajos Varios. S.I.P. 70. Valencia.

LOSADA H. (1966): La necrópolis de la Edad del Hierro de Buenache de Alarcón. (Cuenca). Trabajos de Prehistoria XX. Madrid.

LLATAS, V. (1969): Segunda relación de yacimientos arqueológicos del Villar del Arzobispo y su comarca, Valencia.

MARTÍNEZ, J. M. (1989): La necrópolis ibérica de Las Peñas (Zarra, Valencia), APL 19, 7-76

MARTÍNEZ, V.; MIRALLES, J. A.; MARCO, E. (2001): Astronomia fonamental, Universitat de Valencia.

MATA, C. (1993): Aproximación al estudio de las necrópolis ibéricas valencianas, Homenatge a M. Tarradell, Barcelona, 429-448.

MATA, C.; BONET, H. (1992): La cerámica ibérica: ensayo de tipología, Estudios de arqueología ibérica y romana, Homenaje a Enrique Pla Ballester, Serie Trabajos Varios. S.I.P. 89, 117-173.Valencia.

MILLÁN, J. M. (1990): Una necrópolis tumular en Cuenca: Alconchel, Necrópolis celtibéricas: Necrópolis Celtibéricas. II Simposio sobre los Celtíberos (Daroca, 1988) (F. Burillo, coord.), Zaragoza, 197-202.

MILLÁN, J. M (1995): La necrópolis ibérica del Cerro de la Virgen de la Cuesta (Alconchel de la Estrella, Cuenca), El mundo ibérico. Una nueva imagen en los albores del año 2.000, Junta de Comunidades de Castilla la Mancha, Toledo, 246-250.

MONRAVAL, M. (1992): La necrópolis ibérica de El Molar (S. Fulgencio-Guardamar del Segura, Alicante), Diputación Provincial de Alicante. Alacant.

MORET, P. (1996): Les fortifications ibériques de la fin de l'âge du bronze à la conquête romaine, Collection de la Casa de Velázquez 56, Madrid.

OLIVER, A. (1981): Incineraciones entre el río Ebro y el Palancia. Nuevas aportaciones para el estudio de los enterramientos ibéricos, CPAC 8, 189-256. 
OLIVER, A. (2005): La necrópolis ibérica del Mas Nou de Bernabé en Tirig-Salzadella (Castellón), Sagvntvm-PLAV 37, 45-58.

OLIVER, A. (2014): La necrópolis ibérica de la Solivella: nuevas visiones, nuevas propuestas, CUPAUAM 40, 67-79. DOI: https://doi.org/10.15366/cupauam2014.40.005

PEREIRA, J.; RUIZ, A.; CARROBLES, J. (2003): Aportaciones del C-14 al mundo funerario carpetano: la necrópolis de Palomar de Pintado, TP 60 (2), 153-168.

DOI: https://doi.org/10.3989/tp.2003.v60.i2.87

QUESADA, F.; VALERO, M. A. (2012): Un casco variante del grupo Italo-Calcídico en la necrópolis de Los Canónigos, Arcas del Villar (Cuenca), CUPAUAM 37-38, 349-386. DOI: https://doi.org/10.15366/cupauam2012.38.018

RAFEL, N. (1998): Peus ceràmics reixats de tradició mediterrània en els CU de l'edat del ferro a Catalunya, RAP 8, 81-85.
RODRIGO, C. (1999): Geografía de Andilla. Ayto. de Andilla.

RUBIO, R. (1986): La necrópolis ibérica de la Albufereta de Alicante (Valencia, España), Academia de Cultura Valenciana, Serie arqueológica $\mathrm{n}^{\circ} 11$, Valencia.

UROZ, J. (1984). La regio Edetania en la época ibérica. Instituto de Estudios Alicantinos, Serie II, $\mathrm{n}^{\circ} 23$.

VALERO, M. A. (1999): La necrópolis tumular de la Punta del Barrionuevo. Iniesta-Cuenca, $1^{\text {as }}$ Jornadas de Arqueología Ibérica en Castilla La Mancha, Toledo, 181-208.

VALERO, M. A. (2010): El yacimiento ibérico de Los Canónigos (Arcas del Villar, Cuenca), Nuestro Patrimonio. Recientes actuaciones y nuevos planteamientos en la Provincia de Cuenca, Ciclo de Conferencias, Diputación de Cuenca (Serie Actas, $n^{\circ}$ 3), Cuenca, 161-182. 